\begin{tabular}{|l|c|c|c|r|}
\hline $\begin{array}{l}\text { Cuadernos de Investigación Geográfica } \\
\text { Geographical Research Letters }\end{array}$ & 2017 & N $^{\circ} 43(2)$ & pp. 719-750 & $\begin{array}{r}\text { ISSN 0211-6820 } \\
\text { eISSN 1697-9540 }\end{array}$ \\
\hline
\end{tabular}

DOI: http://doi.org/10.18172/cig.3263

(C) Universidad de La Rioja

\title{
THE LAST GLACIAL MAXIMUM AND DEGLACIATION IN CENTRAL PATAGONIA, $4^{\circ}{ }^{\circ} \mathrm{S}-49^{\circ} \mathrm{S}$
}

\author{
M. MENDELOVA ${ }^{1 *}$,A.S. HEIN ${ }^{1}$, R. MCCULLOCH ${ }^{2}$, B. DAVIES ${ }^{3}$ \\ ${ }^{1}$ School of GeoSciences, University of Edinburgh, Drummond Street, \\ Edinburgh, EH8 9XP, United Kingdom. \\ ${ }^{2}$ Biological and Environmental Sciences, University of Stirling, \\ Stirling, FK9 4LA, United Kingdom. \\ ${ }^{3}$ Centre for Quaternary Research, Department for Geography, Royal Holloway University of London, \\ Egham, Surrey TW20 0EX, United Kingdom.
}

\begin{abstract}
This paper reviews published geochronological data on glacier fluctuations and environmental changes in central Patagonia $\left(44^{\circ} \mathrm{S}-49^{\circ} \mathrm{S}\right)$ from the Last Glacial Maximum (LGM) through to the Holocene. Well-dated glacial chronologies from the southern mid-latitudes can inform on the synchronicity of glacial advances worldwide and provide insight on the drivers of southern hemisphere glaciations. In central Patagonia, two large outlet lobes of the former Patagonian Ice Sheet advanced in broad synchrony with the global LGM. In contrast to other parts of Patagonia, there is no convincing evidence for a more extensive local LGM advance during Marine Isotope Stage 3. Deglaciation initiated at ca. $19 \mathrm{ka}$, earlier than in other parts of Patagonia and regionally in the Southern Hemisphere, and rapid deglaciation saw ice margins retreat in places by at least 80-120 km within a few millennia. The Lateglacial glacier margins are poorly constrained, but an ice mass substantial enough to maintain a large regional proglacial lake must have persisted at this time. The timing of lake drainage and opening of the Rio Baker drainage route to the Pacific Ocean is debated; the only directly dated shoreline suggests this occurred at the end of the Antarctic Cold Reversal at $12.7 \mathrm{ka}$. Palaeoecological evidence for cooling during the Antarctic Cold Reversal or Younger Dryas remains equivocal, which may reflect both the eurythermic nature of Patagonian vegetation and shifting Southern Westerly Winds. Eastern outlet glaciers appear to have advanced or stabilised at the Lateglacial/Holocene transition when palaeoenvironmental records indicate warmer and drier conditions, but the reason for this is unclear. Our review reveals both spatial and temporal gaps in available data that provide avenues for future research.
\end{abstract}




\section{El Último Máximo Glaciar y la deglaciación en Patagonia central, $44^{\circ} S-49^{\circ} S$}

RESUMEN. Este artículo revisa los datos geocronológicos publicados sobre las fluctuaciones de los glaciares y los cambios ambientales en la Patagonia central $\left(44^{\circ} \mathrm{S}-49^{\circ} \mathrm{S}\right)$ desde el Último Máximo Glaciar (LGM) hasta el Holoceno. Las cronologías glaciales bien datadas de las latitudes medias del sur pueden informar sobre la sincronicidad de los avances glaciares en todo el mundo y proporcionar una visión de los factores de las glaciaciones del hemisferio sur. En el centro de Patagonia, dos grandes lóbulos de salida del antiguo Campo de Hielo Patagónico avanzaron en una amplia sincronía con el LGM global. En contraste con otras partes de Patagonia, no hay evidencia convincente de un avance local más extenso que la que tuvo lugar durante el LGM durante la Etapa 3 de Isótopos Marinos. La deglaciación se inició hacia aprox. $19 \mathrm{ka}$, antes que en otras partes de la Patagonia y regionalmente en el hemisferio sur, y la rápida deglaciación vio los márgenes de hielo retroceder en algunos lugares por lo menos $80-120 \mathrm{~km}$ en pocos milenios. Los márgenes de los glaciares del Tardiglaciar están mal delimitados, aunque una masa de hielo sustancialmente suficiente para mantener un gran lago proglaciar regional tuvo que persistir en ese momento. Se discute cuándo ocurrió el drenaje del lago y la apertura de la ruta de drenaje de Río Baker hacia el Océano Pacífico. La única costa directamente datada sugiere que esto ocurrió al final de la Reversión Fría Antártica en $12.7 \mathrm{ka}$. La evidencia paleoecológica del enfriamiento durante la Reversión Fría Antártica o Younger Dryas sigue siendo equívoca, lo que puede reflejar tanto la naturaleza eutérmica de la vegetación patagónica como los vientos del oeste meridionales cambiantes. Los glaciares de salida oriental parecen haber avanzado o estabilizarse en la transición Tardiglaciar/Holoceno cuando los registros palaeoambientales indican condiciones más cálidas y más secas, pero la razón de esto no está clara. Nuestra revisión revela vacíos espaciales y temporales en los datos disponibles que proporcionan vías para la investigación futura.

Keywords: Last Glacial Maximum, deglaciation, Holocene, Patagonia, glacial chronology.

Palabras clave: Último Máximo Glaciar, deglaciación, Holoceno, Patagonia, cronología glacial.

*Corresponding author: Monika Mendelova, School of GeoSciences, University of Edinburgh, Drummond Street, Edinburgh, EH8 9XP, United Kingdom. E-mail address: M.Mendelova@sms.ed.ac.uk 


\section{Introduction}

The former Patagonian Ice Sheet (PIS) extended $2000 \mathrm{~km}$ along the southernmost Andes, between $38^{\circ} \mathrm{S}$ and $55^{\circ} \mathrm{S}$ during the Last Glacial Maximum (LGM; Fig. 1). The ice sheet left a rich glacial geomorphological record of ice limits (e.g. Glasser et al., 2008) that are particularly well preserved east of the mountain front, and which offer the opportunity to constrain the history of ice fluctuations throughout the last glacial cycle. The location in the mid-latitudes of the southern hemisphere, distant from the influence of northern hemisphere ice sheets, makes the site suitable to investigate, for example, the geographic extent of the global LGM and its termination, the interhemispheric linkages of climate variability and the forcing behind southern mountain glaciation.

There is a long history of research on Quaternary glaciations in Patagonia that began in the $19^{\text {th }}$ century leading to the pioneering work of Caldenius (1932), who established the first comprehensive mapping of glacier moraine limits throughout Patagonia. The establishment of glacial chronologies that utilised modern radiometric dating techniques, including radiocarbon $\left({ }^{14} \mathrm{C}\right)$ and potassium-argon (K-Ar), began in the 1960 's through

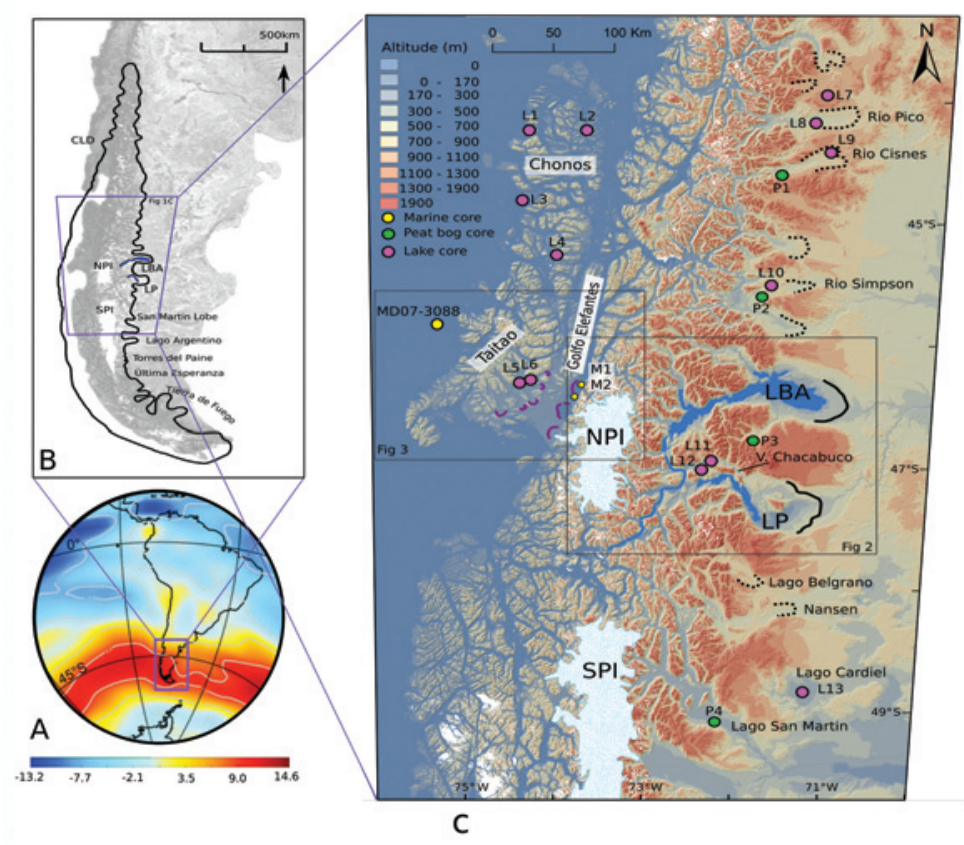

Figure 1. (A) Location of Patagonia, South America, with mean monthly zonal wind strength $\left(\mathrm{m} \mathrm{s}^{-1}\right)$ at 850 hPa based on NCEP/NCAR re-analysis data (modified from Vanneste et al., 2015). (B) Estimated extent of the PIS at the LGM showing sites mentioned in the text; CLD-Chilean Lake District. (C) Map of Central Patagonia showing locations of palaeoenvironmental proxies, which are summarised in Table 1 and ice limits: black - chronologically constrained ice limits, black dashed-assumed LGM limits, purple - undated moraines on the Taitao Peninsula discussed in the text and moraines of the Gualas/Reicher, Rafael, and San Quintín Glaciers (Image: SRTM). 
the work of John Mercer (e.g. Mercer, 1968, 1976, 1982, 1983). Subsequent efforts to develop the glacial history of the PIS have used a wide range of geochronological techniques and are well summarised by several review papers on Quaternary (McCulloch et al., 2000; Rabassa and Clapperton, 1990; Rabassa and Coronato, 2009; Kaplan et al., 2008a; Glasser et al., 2004; Rodbell et al., 2009; Clapperton, 1993; Harrison and Glasser, 2011; Rabassa et al., 2000) and pre-Quaternary (Rabassa et al., 2011) glaciations.

This paper aims to synthesize existing geochronological data on ice limits and environmental changes during the LGM and subsequent deglaciation, in the central part of the former PIS. We review available dating of glacial moraine sequences as well as palaeoenvironmental proxies; the latter are more geographically dispersed in the region and provide insight into postglacial landscape development and climate. We focus on the area surrounding the present day North Patagonian Icefield (NPI), between latitudes $44^{\circ} \mathrm{S}$ and $49^{\circ} \mathrm{S}$ (Fig. 1c), but draw comparisons to other parts of Patagonia. This area has been considered a transitional zone influenced by both Antarctic and Northern Hemisphere climate (Sugden et al., 2005), and is an area where climate models suggest a 'discontinuity' in several climatic components (e.g. wind speed, precipitation) (Rojas et al., 2009). Our review reveals that glacial advances synchronous with the global LGM (gLGM; 26-19 ka; Clark et al., 2009) are constrained at two sites in central Patagonia. Numerous moraines, likely correlative to the local LGM, are found in almost every previously glaciated basin, but have so far received little attention. Tentative evidence suggests pre-LGM advances during the last glacial cycle but further work is needed to constrain these. Deglaciation initiated at about $19 \mathrm{ka}$, somewhat earlier than in southern Patagonia. Ice marginal positions during the Lateglacial are largely unknown, and the occurrence of cooling coeval with the Antarctic Cold Reversal (ACR; 14.5-12.9 ka) or Younger Dryas (YD; 12.9-11.7 ka) is equivocal.

\section{Regional Setting}

The regional geology of the southern Andes is characterized by intrusions of the Patagonian batholith within the Andean Cordillera, Mesozoic and Cenozoic volcanics, Mesozoic marine sediments, and a Paleozoic metamorphic complex (Vandekerkhove et al., 2016; Lagabrielle et al., 2004). The Taitao Peninsula and Chonos Archipelago are formed of Triassic metamorphic rocks and mid-Cenozoic volcanic and sedimentary deposits, with the Patagonian batholith constraining the eastern edges. Basins to the east of the Andes are filled with Pliocene-Quaternary glacial and glaciofluvial sediments (Vandekerkhove et al., 2016; Lagabrielle et al., 2004). A gap in the active volcanic arc between the Southern Andean Volcanic Zone and Austral Andean Volcanic Zone exists in central Patagonia ( $\left.46.5^{\circ} \mathrm{S}-49^{\circ} \mathrm{S}\right)$, near the Chile Triple Junction, where the Nazca, South American and Antarctic tectonic plates meet (Gutiérrez et al., 2005; Stern, 2004).

The region contains the highest mountain in the Patagonian Andes, Mt. San Valentin at $4058 \mathrm{~m}$, which is situated on the northern flank of the NPI. The otherwise topographically continuous chain of the Andes exhibits a break in central Patagonia between latitudes $47^{\circ} \mathrm{S}$ and $48^{\circ} \mathrm{S}$. This gap is occupied by the Río Baker, which drains the eastern outlet glaciers of the NPI, including the large cross-border lakes of Lago Buenos Aires/Lago 
General Carrera (LBA) and Lago Pueyrredón/Lago Cochrane (LP) westwards into the Pacific Ocean (Fig. 1c). Therefore, the water divide is unusually located $170 \mathrm{~km}$ to the east of the mountain chain. The landscape east of the Andes is characterized by west-east trending over-deepened valleys separated by volcanic plateaus. To the west of the Andes, the landscape is dominated by an extended fjord and island system. The ice flow during successive glaciations exploited pre-existing structural faults, and over-deepened and widened the fjords and valleys through selective erosion (Glasser and Ghiglione, 2009).

The Patagonian Andes of southern South America are situated in the mid-latitudes of the Southern Hemisphere, where the landmass intersects important global atmospheric and oceanic systems. These include the Southern Hemisphere Westerly Winds (SWWs) (Fig.1a), which play a role in modulating global climate through their influence on ocean currents and ventilation of the deep Southern Ocean (Toggweiler et al., 2006; Garreaud et al., 2013). The SWWs bring precipitation that feeds the largest temperate ice fields in the Southern Hemisphere, the NPI and the South Patagonian Icefield (SPI) (Warren and Sugden, 1993). In addition to these icefields, two smaller icefields, the Cordillera Darwin and Gran Campo Nevado, along with numerous smaller glaciers are all that remain of the former PIS. The present day NPI covers an area of $3976 \mathrm{~km}^{2}$ (Davies and Glasser, 2012), contains $1234.6 \mathrm{~km}^{3}$ of ice (3.10 mm sea-level equivalent) (Carrivick et al., 2016) and has a mean ice thickness of $305 \mathrm{~m}$. The equilibrium line altitude ranges from $\sim 900 \mathrm{~m}$ in the west to $\sim 1300 \mathrm{~m}$ in the east (Rivera et al., 2007).

The strong circulation at the core of the SWWs $\left(49^{\circ} \mathrm{S}-53^{\circ} \mathrm{S}\right)$ is due to limited land at these latitudes, resulting in low friction and a strong pressure gradient between the cold Antarctic and warm subtropics (Aravena and Luckman, 2009; Garreaud et al., 2009). The Patagonian Andes act as the only significant barrier to the SWWs, causing a strong orographic effect, as a result forming an extreme climate divide. Precipitation in the west exceeds $3000 \mathrm{~mm} \mathrm{yr}^{-1}$, reaching $6000 \mathrm{~mm} \mathrm{yr}^{-1}$ (in places up to $10,000 \mathrm{~mm} \mathrm{yr}^{-1}$ ) on the mountain tops, and dropping to less than 100-200 $\mathrm{mm} \mathrm{yr}^{-1}$ within $100 \mathrm{~km}^{2}$ east of the Andean foothills (Garreaud, 2009). The precipitation gradient creates distinct vegetation zones. In central Patagonia, the North Patagonian rainforest dominates humid western islands and mountain slopes, along with moorland covering some islands. On the leeward mountain side, subantarctic deciduous forest transitions through shrubland to the Patagonian steppe in the semi-arid zone. Subantarctic rainforest fills the gap between the NPI and SPI.

\section{Methods}

For the purpose of this review we have re-calculated all geochronological data from central Patagonia. Radiocarbon ages were recalculated using the OxCal 4.3 online calibration tool (Bronk Ramsey, 2009) and the ShCal13 Southern Hemisphere calibration curve (Hogg et al., 2013), and are presented in the text as median cal ka BP. For cosmogenic ${ }^{10} \mathrm{Be}$ surface exposure ages, we used the online exposure age calculator formerly known as the CRONUS-Earth online calculator (v. 2.2; constants v.2.2.1; Balco et al., 2008) and the local ${ }^{10} \mathrm{Be}$ production rate for southern Patagonia (Kaplan et al., 2011). Cosmogenic ${ }^{36} \mathrm{Cl}$ ages have been re-calculated using the CRONUScalc web calculator (Marrero et al., 2016a) and production rates presented by Marrero et al. (2016b). Ages for moraines 


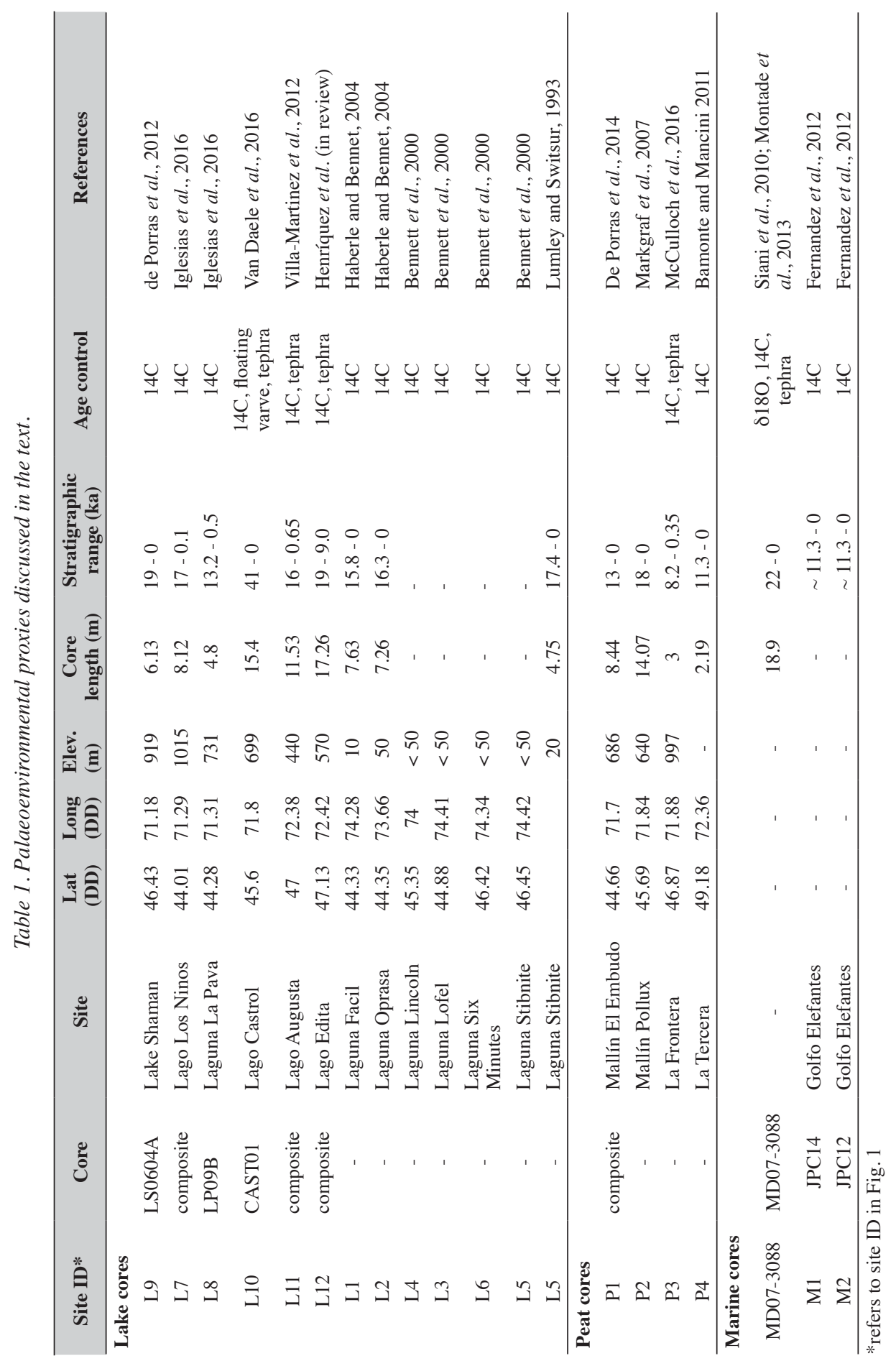


based on multiple cosmogenic nuclide analyses were derived from camel plots and are presented as the probabilistic peaks. The outliers identified in the original publications were removed from the camel plots. All exposure ages assume zero rock surface erosion and no shielding (snow, soil, loess, vegetation) and thus are minimum ages. However, inclusion of an erosion rate of $0.2 \mathrm{~m} \mathrm{Ma}^{-1}$ derived in the LBA valley on the basis of paired ${ }^{36} \mathrm{Cl} /{ }^{10} \mathrm{Be}$ concentrations (Douglass et al., 2007), increases an LGM age by less than $1 \%$, and thus is well within the reported internal uncertainties. Individual exposure ages are presented with $1 \sigma$ external uncertainties to allow comparison to radiocarbon ages. The data used to calculate the exposure ages are presented in Supplementary Table 1 (Available at: http:publicaciones.unirioja.es/revistas/cig2017/Mendelova_TableS1.xlsx). The original publications should be consulted for the original data and further information.

\section{Glacial History}

Mapping and dating of glacial limits has been done primarily along the eastern flank of the Patagonian Andes. The geomorphological record here is exceptionally well preserved due in part to the arid climate on the eastern side of Andes. Here, moraine systems can be found in nearly every valley between $38^{\circ} \mathrm{S}$ and $56^{\circ} \mathrm{S}$, and often are associated with, or confine large lakes. In the past decade the application of cosmogenic nuclide surface exposure dating and optically stimulated luminescence (OSL) has led to an increase in the concentration and geographic range of glacial chronologies. Numerous well-dated chronologies have been developed in southern Patagonia and Tierra del Fuego (e.g. Darvill et al., 2015; Kaplan, et al., 2008b; McCulloch et al., 2005b). With the exception of two well-dated chronologies from LBA and LP, glacial chronologies remain sparse in central Patagonia, and at the time of writing there are no published chronologies for NE Patagonia. To the west of the Andes, the PIS terminated in the ocean during the LGM and most geomorphological evidence is therefore submarine, with the exception of north-western Patagonia including the Chilean Lake District, where glaciers terminated on land and their advances over the last glacial cycle have been well documented (Denton et al., 1999).

Regional distribution of palaeoenvironmental records largely depends on the availability of suitable natural archives (e.g. peat bogs, lakes). However, the location of study sites is also biased towards the east in part due to the limited accessibility of the Chilean fjords, with the exception of Isle Grande Chiloé in north-western Patagonia, and the Chonos Archipelago and Taitao Peninsula in central-western Patagonia. Swath bathymetry can reveal submarine geomorphological evidence and it has been applied in the southern Chilean fjords (e.g. Dowdeswell et al., 2016; Dowdeswell and Vásquez, 2013). Less is known about the bathymetry of the fjords between $44^{\circ} \mathrm{S}$ and $46^{\circ} \mathrm{S}$ (Völker et al., 2013).

Between latitudes $44^{\circ} \mathrm{S}$ and $49^{\circ} \mathrm{S}$, the former PIS drained eastwards by ten topographically controlled outlet glaciers and ice lobes, which extended onto the Andean plains during the LGM (Glasser and Jansson, 2005; Glasser et al., 2008). Each of these outlet glaciers left behind a series of moraine limits (Fig. 2). To date, however, most research efforts have focused on just two of these formerly glaciated basins: LBA and LP. Here, argon-argon $\left({ }^{40} \mathrm{Ar} /{ }^{39} \mathrm{Ar}\right)$ dating of basaltic lava flows interbedded with the glacial deposits, 
cosmogenic nuclide surface exposure dating, soil formation rates and OSL dating have been used to date glacial advances spanning from the Greatest Patagonian Glaciation (ca. 1.1 Ma) through to the last glacial cycle (e.g. Singer et al., 2004; Douglass and Bockheim, 2006; Kaplan et al., 2004; Smedley et al., 2016; Hein et al., 2010). Moraine systems in the other basins, which probably relate to the last glacial cycle, or older, have received little attention. Younger, likely Lateglacial to Holocene moraines are found within the Andean valleys closer to the NPI and present day mountain glaciers. On the western side of the Andes, terrestrial geomorphological evidence is confined to the Taitao Peninsula (Fig. 1c).

The locations of environmental proxies discussed in the paper are shown in Figure 1c and are listed in Table 1. On the western side of the Andes, several peat bog and lake cores have been obtained from the Taitao Peninsula and the Chonos Archipelago, which cover the Lateglacial and Holocene period. A marine core (MD07-3088) recovered off the Taitao Peninsula $\left(46^{\circ} \mathrm{S}\right)$ provides a high-resolution pollen, clay mineralogy and major geochemistry record covering the last $22 \mathrm{ka}$ (Siani et al., 2010; Montade et al., 2013). Multiple peat bog and lake cores have been sampled from valleys along the eastern flank of the Andes and provide a record covering the Lateglacial and Holocene. Minimum radiocarbon ages for deglaciation are listed in Table 2 . In the following, we describe the data that constrain the LGM and the onset of deglaciation, the Lateglacial and the Holocene from the western and eastern side of the Andes.

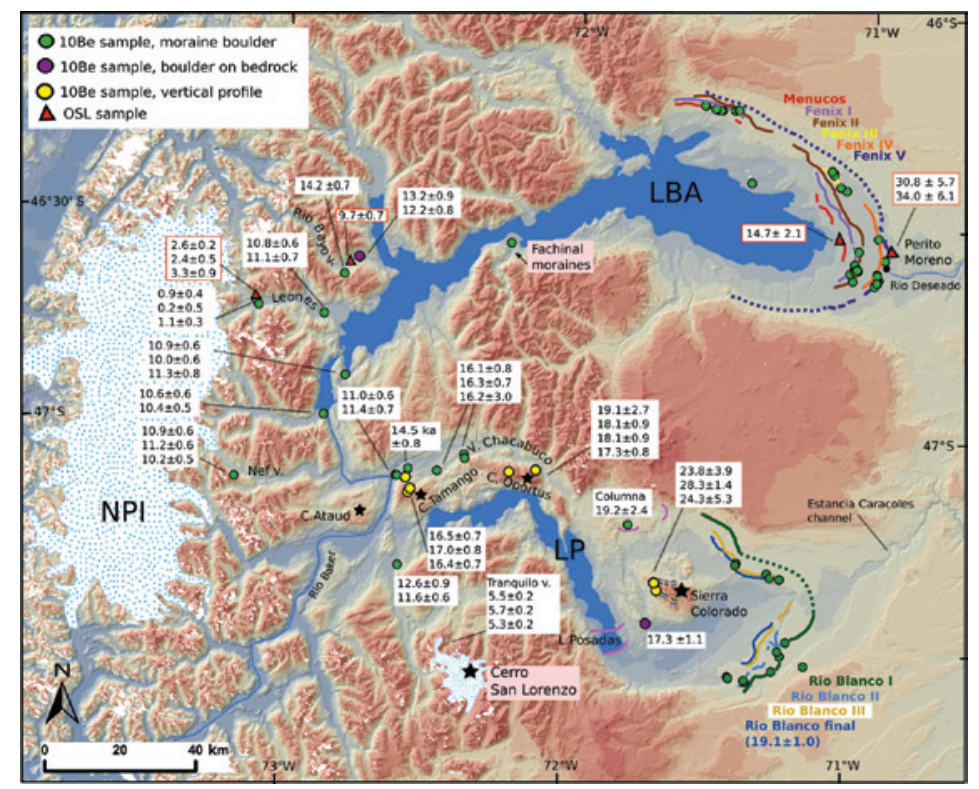

Figure 2. North Patagonian Ice Field (NPI), Lago Buenos Aires/Lago General Carrera (LBA) and Lago Pueyrredón/Lago Cochrane (LP)showing geochronological data (in ka) and delineated moriane limits, Fenix and Río Blanco, corresponding to the global Last Glacial Maximum, Columna and Lago Posadas moraines (pink), and lateral moraines on Sierra Colorado. Camel plots showing age distribution for Fenix, Rio Blanco limits, and Fachinal moraines are presented in Figs. 4 - 6, respectively. 


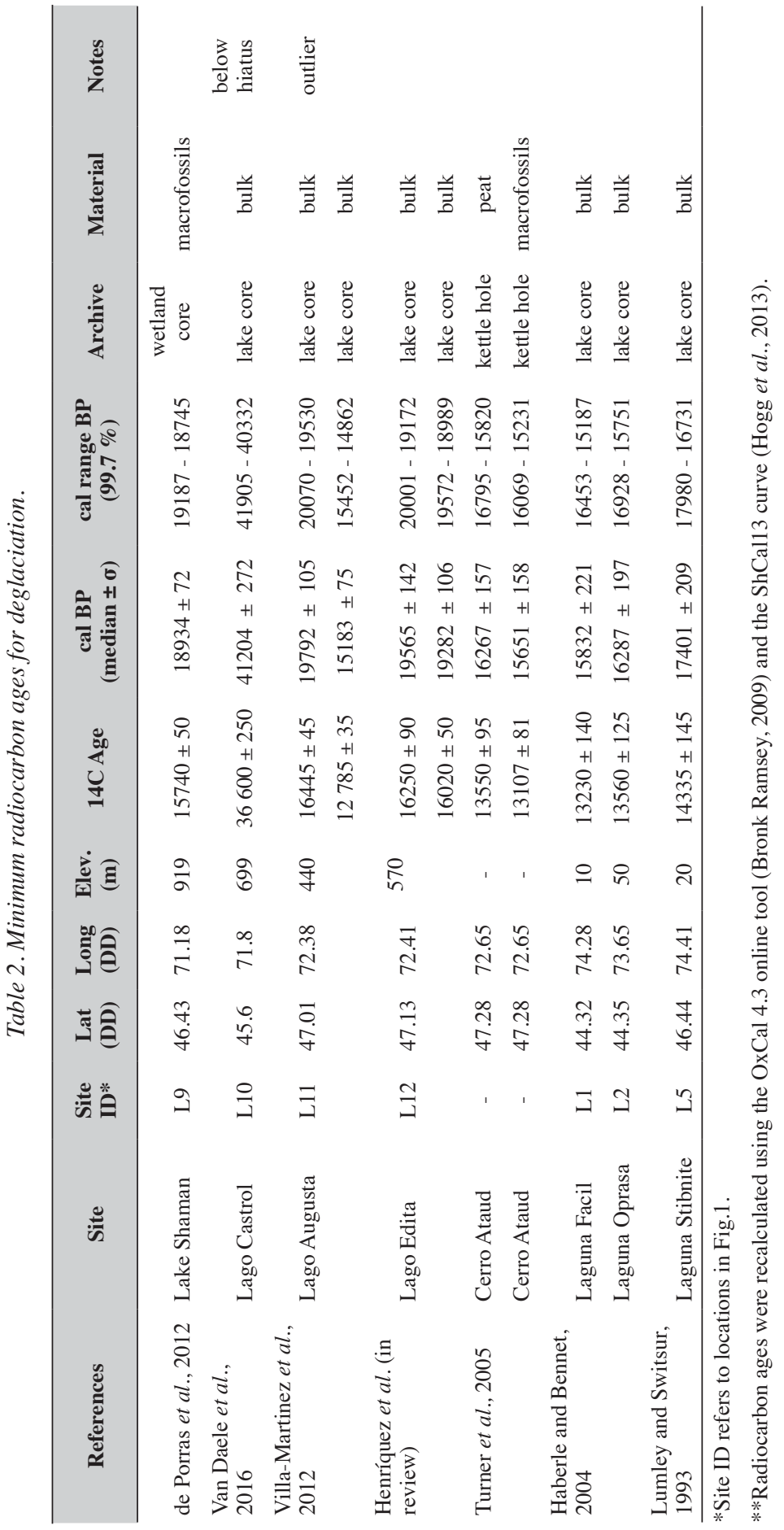




\subsection{Last Glacial Maximum}

\subsubsection{Western Andes}

At the LGM, the PIS is thought to have extended over the western islands and terminated in the ocean near the continental shelf edge (Hubbard et al., 2005). As a consequence, there is no direct field evidence on the extent and timing of glacier advances during the LGM. However, a terrigenous sediment record recovered from immediately offshore of the Taitao Peninsula (Fig. 1c) was used to infer glacial advances at 21.6-20.9 ka, 20.2-20 ka, 19.6-19.1 ka and 18.5-18 ka, based on rapid short-term fluctuations of smectite/ (illite + chlorite) and titanium/potassium (Siani et al., 2010). The record indicates increased erosion of the Coastal Range of Chile due to glacier dynamics until ca. $18 \mathrm{ka}$. An increase in the sediment input from the Andean Cordillera after $18 \mathrm{ka}$ suggests the withdrawal of the ice margin from the western island zone by this time (Siani et al., 2010). Minimum radiocarbon ages from Laguna Stibnite suggest that the Taitao Peninsula was ice free by $17.4 \pm 0.2 \mathrm{cal}$ ka BP (Lumley and Switsur, 1993), and the northern parts of the Chonos Archipelago by $16.3 \pm 0.2 \mathrm{cal}$ ka BP (Haberle and Bennett, 2004).

On the Taitao Peninsula, a series of arcuate terminal moraines indicate that valley glaciers flowing east and south from the centre of the peninsula drained an independent ice cap (Fig. 3) (Heusser, 2002; Glasser et al., 2008). In one locality (Laguna Elena), at least twelve distinct moraines indicate multiple re-advances or still-stands (Heusser, 2002). The age of these moraines is unknown, but on the basis of a minimum radiocarbon age for deglaciation of the peninsula (17.4 $\pm 0.2 \mathrm{cal}$ ka BP) (Lumley and Switsur, 1993),

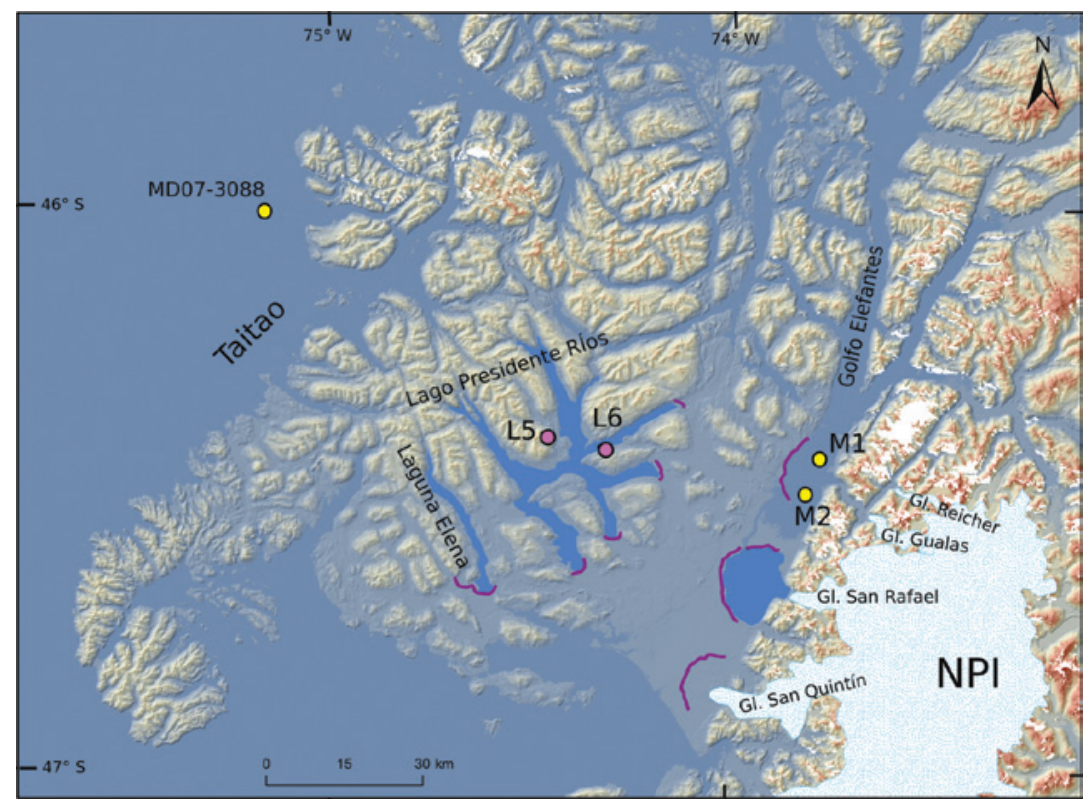

Figure 3. The Taitao Peninsula and adjacent Cordillera showing the locations of undated moraines (purple) discussed in the text, and offshore and lake sediment cores. 
it has been suggested that they might date to the LGM (Heusser, 2002). If correct, this would imply either the limited expansion of the PIS to the west at the LGM, or that the deep Golfo Elefantes prevented the ice sheet from overrunning the Taitao Peninsula (Glasser et al., 2008). In the former case, the climatological conditions that would allow for growth of an ice cap on the low-lying peninsula, but not support ice expansion from the Cordillera are unclear (Glasser et al., 2008), and the scenario is difficult to reconcile with LGM ice expansion further north in the Chilean Lake District (Denton et al., 1999). The latter case also seems improbable given that there is morainic evidence to show that the NPI outlet glaciers (Gualas/Reicher Glaciers) advanced over Golfo Elefantes (Heusser, 2002). An alternative is that the moraines on the Taitao Peninsula were deposited during late LGM still-stands, shortly after the separation of the Taitao ice cap from the PIS, and prior to rapid deglaciation on the peninsula.

\subsubsection{Eastern Andes}

Ten outlet glaciers drained the former PIS between $44^{\circ} \mathrm{S}$ and $49^{\circ} \mathrm{S}$ (Glasser et al., 2008). Several moraine systems can be found at the eastern end of these formerly glaciated basins. While predominantly undated, the innermost moraines have been tentatively correlated to the LGM (Fig. 1c) (Glasser et al., 2008). Rabassa et al. (2011) provided a summary of earlier studies that described the drifts and moraines in these basins. In the absence of direct dating of the moraines, radiocarbon ages from lake and peat bog cores provide a minimum deglaciation age (Table 2). In the Río Cisnes valley ( $44.7^{\circ} \mathrm{S}$; Fig. 1), a minimum radiocarbon age from an intermorainic lake (Lago Shaman) indicates that ice abandoned the innermost moraine system before $18.9 \pm 0.1 \mathrm{cal} \mathrm{ka}$ BP (de Porras et al., 2012). Further upstream, a core from Mallín El Embudo, suggests that the middle part of the Río Cisnes valley was occupied by a proglacial lake until ca. $13 \mathrm{cal} \mathrm{ka}$ BP (de Porras et al., 2014). Further south in the Río Simpson basin $\left(45.6^{\circ} \mathrm{S}\right)$, a minimum radiocarbon age of $41.2 \pm 0.3 \mathrm{cal} \mathrm{ka} \mathrm{BP}$ was obtained from Lago Castor. However, a hiatus in the stratigraphy suggests that a later readvance over the site might have occurred (Van Daele et al., 2016).

Cosmogenic ${ }^{10} \mathrm{Be}$ ages from moraine boulders revealed that the LBA outlet lobe $\left(46.5^{\circ} \mathrm{S}\right)$ reached its maximum extent sometime between $27-25 \mathrm{ka}$ as marked by the Fenix V moraine (Figs. 2, 4). Four subsequent readvances or still-stands are indicated by the Fenix IV-I moraines, with the final advance at ca. $19.3 \mathrm{ka}\left({ }^{10} \mathrm{Be}\right.$ peak age, Fenix I) (Douglass et al., 2006; Kaplan et al., 2004). Cosmogenic ${ }^{10} \mathrm{Be}$ ages from moraine boulders on the Río Blanco moraine system showed that the LP ice lobe $\left(47.5^{\circ} \mathrm{S}\right)$ reached its maximum extent at ca. $28.0 \mathrm{ka}\left({ }^{10} \mathrm{Be}\right.$ peak, Río Blanco I), a little earlier than the LBA outlet (Hein et al., 2010; Hein et al., 2009). Three subsequent re-advances or still-stands are evident by the Río Blanco II-III moraines, with a final advance dated at ca. $21.6 \mathrm{ka}\left({ }^{10} \mathrm{Be}\right.$ peak; Fig. 5) (Hein et al., 2009, 2010). ${ }^{10} \mathrm{Be}$ ages from boulders and bedrock along a mountain transect separating the LP and Chacabuco valleys were used to reconstruct ice surface profiles (Boex et al., 2013). Lateral moraines on Sierra Colorado ( 1170 m a.s.1.) (Fig. 2) yielded ${ }^{10} \mathrm{Be}$ ages of $23.8 \pm 3.9,28.3 \pm 1.4$ and $24.3 \pm 5.3 \mathrm{ka}$, thus corresponding to the Río Blanco terminal limits as indicated by 


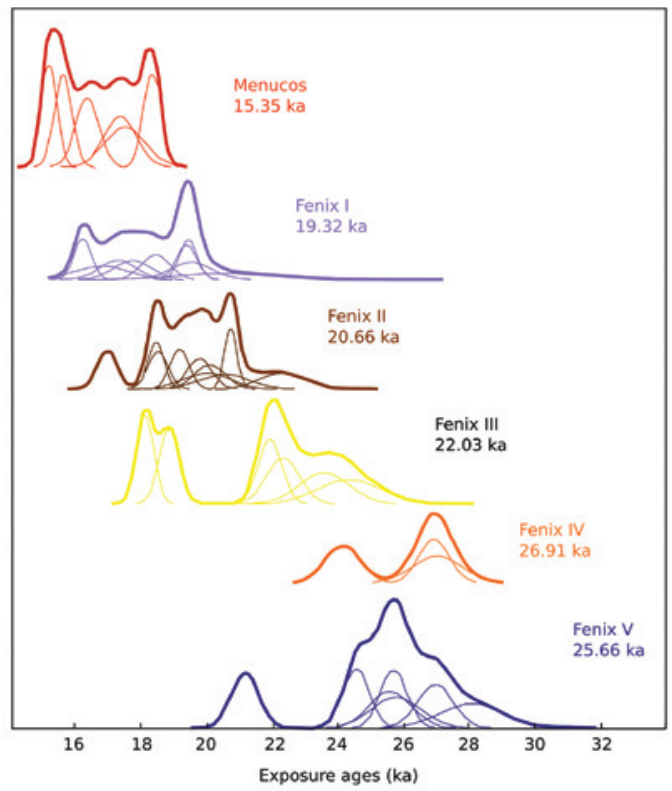

Figure 4. Camel plots summarising distribution of ${ }^{10}$ Be ages for each of the Fenix moraine limits and Menucos limit, outliers identified in the original publications were removed. Thin lines represent individual Gaussian probability distributions for ${ }^{10} \mathrm{Be}$ ages with $1 \sigma$ internal error; thick line represents the sum of the individual probability distributions.

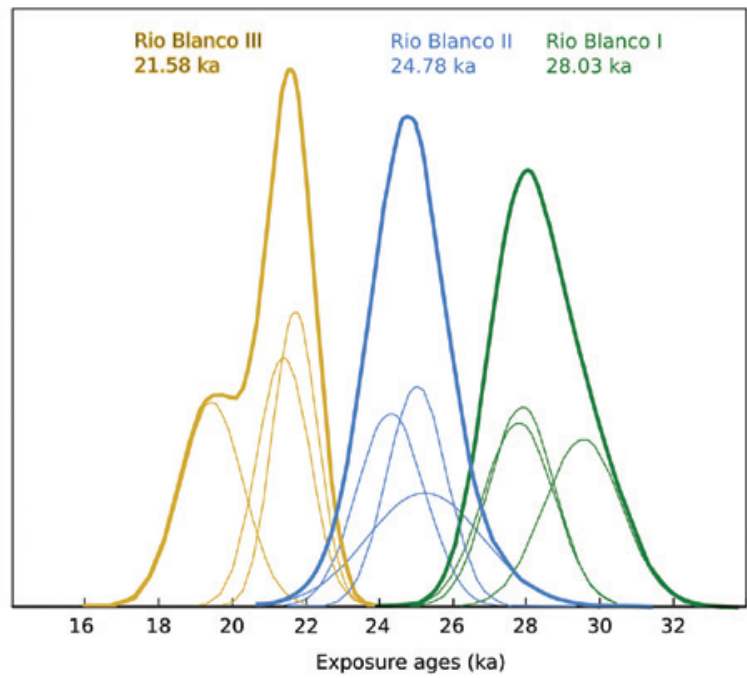

Figure 5. Camel plots summarising distribution of ${ }^{10}$ Be ages for each of the Rio Blanco moraine limits, outliers identified in the original publications were removed. Thin lines represent individual Gaussian probability distributions for ${ }^{10}$ Be ages with $1 \sigma$ internal error; thick line represents the sum of the individual probability distributions. 
geomorphological mapping. The profiles revealed that the LP lobe had a low surface gradient and a maximum thickness of $\sim 1100 \mathrm{~m}$ at this location, a result consistent with previous modelling (Hubbard et al., 2005).

Recently, Smedley et al. (2016) reported OSLages of $30.8 \pm 5.7 \mathrm{ka}$ and $34.0 \pm 6.1 \mathrm{ka}$ from glacial outwash related to the Fenix moraines (LBA). They concluded that an earlier ice advance occurred and deposited the outwash, but the corresponding moraine was not preserved. It is likely the moraine was overrun by a subsequent ice advance or removed by meltwater. These results suggest the local LGM may have occurred earlier than indicated based on the preserved moraine record. Supporting evidence for an earlier advance comes from a single ${ }^{10} \mathrm{Be}$ age from a boulder on a small moraine crest just outside of the outermost Río Blanco limit in the LP valley that gave an age of $35.1 \pm 1.2 \mathrm{ka}$ (Hein et al., 2010). The retreat of the ice margin initiated at approximately the same time in both the LBA and LP valleys at ca. $19 \mathrm{ka}$, and coincided with the onset of ice surface lowering revealed by the vertical reconstruction of the ice sheet surface in the LP/Chacabuco valleys (Boex et al., 2013). The initial deglaciation in both valleys was interrupted by subsequent re-advances. The LBA outlet lobe initially retreated to an unknown distance, leading to the formation of a proglacial lake. A subsequent readvance then deposited the Menucos moraine above varved lake sediment (Douglass et al., 2006; Kaplan et al., 2004; Turner et al., 2005). Cosmogenic ${ }^{10} \mathrm{Be}$ ages from moraine boulders on the Menucos moraine yielded range between $18.3 \mathrm{ka}$ and $15.2 \mathrm{ka}$ (Douglass et al., 2006). Given that most geological processes act to reduce apparent exposure ages, the older ages of $18.3 \mathrm{ka}$ are probably more representative of the true age of the moraine. Cemented-carbonate concretions in the stratigraphically older varved sediments gave three radiocarbon ages of $15.3 \pm 0.3,15.3 \pm 0.2$, and $17 \pm$ 0.5 cal ka BP (Kaplan et al., 2004; Sylwan, 1989). However, these ages should be interpreted with caution as the origin of carbonate concretions is uncertain (Hein et al., 2010). Smedley et al. (2016) reported an OSL age of $14.7 \pm 2.1 \mathrm{ka}$ from glaciofluvial sediment stratigraphically older than Menucos moraine, and thus there remains an element of uncertainty on the age of the Menucos moraines. After their deposition, the glacier most likely retreated permanently back into the LBA basin.

A re-advance or still-stand also occurred in the LP and Chacabuco valleys depositing the Lago Posadas and Lago Columna moraines (Hein et al., 2010). There are limited data to constrain the age of these moraines. A boulder on the Columna moraine yielded a ${ }^{10} \mathrm{Be}$ age of $19.2 \pm 2.4 \mathrm{ka}$ (Boex et al., 2013), and a boulder on bedrock in the LP valley, which provided a minimum age for the readvance, had a ${ }^{10} \mathrm{Be}$ age of $17.3 \pm 1.1 \mathrm{ka}$ (Hein et al.,2010). The latter age, which came from an erratic that was submerged in a pro-glacial lake, was also used to infer ice retreat of more than $80 \mathrm{~km}$ and draining of the lake by this time. Rapid thinning initiated at ca. $18 \mathrm{ka}$, as revealed by ${ }^{10} \mathrm{Be}$ ages constraining the ice surface elevation, which lowered to expose both Cerro Oportus and Cerro Tamango completely in approximately 1000 years, equivalent to about $1000 \mathrm{~m}$ of ice-surface lowering (Boex et al., 2013). The Lago Augusta $(440 \mathrm{~m})$ and Lago Edita $(570 \mathrm{~m})$ lake records indicate that the Chacabuco Valley was ice free and no longer inundated by a proglacial lake by $15.2 \pm 0.1$ cal ka BP 
(Villa-Martínez et al., 2012), or as early as $19.6 \pm 0.1$ cal ka BP (Henríquez et al., 2017). Two radiocarbon ages obtained from a kettle hole near Cerro Ataud, interpreted as minimum deglaciation ages, indicate that the ice had receded close to the Andean foothills by ca. 16 cal ka BP (Turner et al., 2005). Cosmogenic ${ }^{10} \mathrm{Be}$ ages for the Río Blanco moraines (Hein et al., 2010), Columna moraine, vertical ice surface profiles, minimum radiocarbon deglaciation ages and the Lago Augusta stratigraphy all appear consistent, within uncertainties, suggesting rapid deglaciation of more than $100 \mathrm{~km}$ occurred between ca. $19 \mathrm{ka}$ and $16 \mathrm{ka}$.

There is growing evidence to suggest that in north-western and southern Patagonia, the local LGM occurred during Marine Isotope Stage (MIS) 3, earlier than in central Patagonia. On Tierra del Fuego, the Bahía Inútil-San Sebastián ice lobe (53-54 S) advanced about $100 \mathrm{~km}$ beyond the global LGM limit at $45.6 \mathrm{ka}$ and $30.1 \mathrm{ka}$ (Darvill et al., 2015). Sagredo et al. (2011) dated the local maxima of the Última Esperanza lobe $\left(51-52^{\circ} \mathrm{S}\right)$ to ca. $39 \mathrm{ka}$, and found no limits corresponding to the global LGM. Two exposure dates from a moraine in the Lago San Martin valley $\left(49^{\circ} \mathrm{S}\right)$ tentatively indicate an advance at about 34-37 ka (Glasser et al., 2011). In north-western Patagonia, the radiocarbon chronology from the Chilean Lake District revealed advances at 33.6 cal ka BP and 30.8 cal ka BP (Denton et al., 1999). Pre-LGM advances have been documented elsewhere in the Southern Hemisphere as well; in New Zealand, the Ohau Glacier $\left(44^{\circ} \mathrm{S}\right.$ ) advanced at $32 \mathrm{ka}$ (Putnam et al., 2013), the Pukaki Glacier $\left(44^{\circ} \mathrm{S}\right.$ ) advanced at $\sim 65 \mathrm{ka}$ (Schaefer et al., 2015) and again at $42 \mathrm{ka}$ (Kelley et al., 2014), and the Mt. Field glaciers in Tasmania advanced at 44-41 ka (Mackintosh et al., 2006).

Deglaciation of the LBA, LP and Chacabuco valleys preceded the onset of warming (18 ka) identified in a marine core off Taitao peninsula (Montade et al., 2013; Siani et al., 2010) and field evidence suggests that deglaciation occurred earlier and more rapidly than predicted by modelling experiments (Hubbard et al., 2005). Deglaciation in central Patagonia appears to have initiated about 1000 years earlier than in southern Patagonia or the Chilean Lake District. Recession of the Última Esperanza ice lobe started after $17.5 \mathrm{ka}$ (Sagredo et al., 2011), deglaciation in Torres del Paine was underway by ca. 17.4 ka (García et al., 2014), the Strait of Magellan and Bahía Inútil were underway by ca. $17 \mathrm{ka}$ (Kaplan et al., 2008b; McCulloch et al., 2005a), and in the Chilean Lake District, ice recession was underway by ca. 17.8 ka (Moreno et al., 2015; Denton et al., 1999). The timing is similar to the onset of deglaciation in New Zealand (Rother et al., 2015; Putnam et al., 2013; Kelley et al., 2014; Doughty et al., 2015; Schaefer et al., 2006). The cause of early, rapid deglaciation in central Patagonia likely stems from many processes. Rapid deglaciation here has been linked to southward migration of the SWWs and regional warming (Boex et al., 2013), which could also help to explain the comparatively early deglaciation. Modelling experiments indicate the PIS in central Patagonia is stable in two states, full glacial and full interglacial (Hubbard et al., 2005). At these times, the ice sheet is relatively insensitive to changes in climate. However, during deglaciation, the modelling suggests the ice sheet reached a tipping point where it rapidly switched between stable states and deglaciated, losing some $85 \%$ of its volume in 800 years (Hubbard et al., 2005). Thus, while the trigger for initial deglaciation will relate to an external driver, the feedbacks within the system, 
including the change in dynamics associated with ice calving into deep pro-glacial lakes, must play a significant role in the rapidity of ice decline following the LGM.

\subsection{The Lateglacial}

\subsubsection{Western Andes}

On the western side of the Andes there are no directly dated Lateglacial ice limits. There are a series of moraines indicating an expansion of the NPI outlet glaciers (San Quintín, San Rafael and Gualas/Reicher Glaciers) to form three piedmont lobes. It has been suggested that these moraines might be correlative (Heusser, 2002). Tentatively dated sedimentological records suggest that Golfo Elefantes remained ice free since ca. $11.3 \mathrm{ka}$, and thus the moraines deposited along its western edge by the Gualas/Reicher Glacier are probably older than this age (Fernandez et al., 2012). The San Rafael Glacier advanced into a pre-existing moraine system during the early Holocene (see section 4.3.1.). The exact timing for the formation of these piedmont lobes remains to be established. The existing evidence suggests the Taitao Peninsula and the Chonos Archipelago likely remained ice free for most of the Lateglacial.

In the marine pollen record, gradual Nothofagus forest expansion was recorded from ca. $17.6 \mathrm{cal}$ ka BP, representing a first step of warming (Montade et al., 2013). Closed Nothofagus-Pilgerodendron-Podocarpus forest developed across the Chonos Archipelago and Taitao Peninsula between 14-13 cal ka BP and showed no reductions in the forest cover once a closed forest became established (Haberle and Bennett, 2004; Bennett, 2000; Lumley and Switsur, 1993). Humid rainforests, once established, tend to be insensitive to smaller climatic changes. However, a high-resolution marine pollen record indicated there was an increase in Magellanic moorland (Astelia) at $14.5 \mathrm{cal} \mathrm{ka}$ $\mathrm{BP}$, interpreted as a sudden precipitation increase accompanied by a pause in the warming trend and coinciding with the ACR. The subsequent retreat of the Magellanic moorland after $12.8 \mathrm{cal}$ ka BP marks the second warming step during the Lateglacial and provides a strong evidence for the end of the ACR (Montade et al., 2013). A Chironomid record from Laguna Stibnite (Taitao Peninsula) shows a peak in abundance of Podonominae between 13.1-10.5 cal ka BP, interpreted as indicative of cool and oligotrophic lake waters. The changes in the chironomid assemblages were small, however, and any cooling during this period, coeval with the YD would have been minimal (Massaferro and Brooks, 2002).

\subsubsection{Eastern Andes}

\subsubsection{Glacier advances}

Evidence for the extent of glaciers during the Lateglacial is sparse on the eastern side of the Andes. Four moraines deposited by Tranquilo Glacier, Cerro San Lorenzo, were dated to the ACR using ${ }^{10} \mathrm{Be}$ (E. Sagredo, personal communication, 2017). These provide the only direct evidence for an ACR glacier re-advance in central Patagonia. A single ${ }^{10} \mathrm{Be}$ age of $14.2 \pm 0.7 \mathrm{ka}$ from the Lago Tranquilo cirque moraine, and two ${ }^{10} \mathrm{Be}$ ages of $13.2 \pm 0.9$ and $12.2 \pm 0.8 \mathrm{ka}$, from boulders on bedrock in the Río Bayo valley have also been reported (Glasser et al., 2006). Unlike moraines, exposure ages from 
boulders on bedrock do not represent advances or still-stands, but in this case they do suggest that the ice margin withdrew to within $\sim 30 \mathrm{~km}$ of the present day margin by ca. 13 ka. Glasser et al. (2012) obtained ${ }^{10} \mathrm{Be}$ ages from moraines in several valleys east of the present day NPI (Fig. 2), ranging from ca. 11.4-10.0 ka, which represent advances near the Lateglacial/Holocene transition. Although most of these moraines have apparent early Holocene exposure ages, within uncertainties, they might represent the culmination of YD advances/still-stands (Glasser et al., 2012). We note that in certain locations east of the NPI, such Lateglacial advances may be intricately linked with the development of regional lakes that have the potential to complicate surface exposure ages if samples had been submerged.

In contrast, Lateglacial glacier advances are well-documented in southern Patagonia. Robust radiocarbon and cosmogenic nuclide chronologies from Lago Argentino $\left(50^{\circ} \mathrm{S}\right.$; Fig. 1) showed that outlet glaciers advanced during the ACR, deposited the Puerto Bandera moraines, and subsequently retreated during the YD, reaching within $20 \mathrm{~km}$ of the present day glacier margins by $12.2 \mathrm{ka}$ (Strelin et al., 2011; Kaplan et al., 2011; Ackert et al., 2008). ${ }^{10} \mathrm{Be}$ and radiocarbon chronologies from Torres del Paine $\left(51^{\circ} \mathrm{S}\right)$, revealed that the outlet glaciers of the SPI re-advanced during the ACR and ice recession was underway by about $12.5 \mathrm{ka}$ (García et al., 2012; Moreno et al., 2009; Fogwill and Kubik, 2005). There is geomorphic and stratigraphic evidence for a re-advance of the Última Esperanza lobe $\left(52^{\circ} \mathrm{S}\right)$, tentatively assigned to 14.8-12.8 ka (Sagredo et al., 2011). In Tierra del Fuego $\left(54.6^{\circ} \mathrm{S}\right),{ }^{10} \mathrm{Be}$ ages from cirque moraines showed deposition contemporaneous with the ACR (Menounos et al., 2013). A re-advance of the Cordillera Darwin outlet glaciers into the Strait of Magellan, coeval with the ACR, has been suggested by McCulloch et al. (2005a, 2005b). Still-stands or minor re-advances coeval with the YD interrupted the overall ice retreat from the maximum ACR position at numerous sites in southern Patagonia (Strelin et al., 2011; Moreno et al., 2009; Kaplan et al., 2011). A similar pattern of glacier advances culminating at the end of the ACR, followed by retreat during the YD has been documented in New Zealand (Kaplan et al., 2010; Kaplan et al., 2013; Putnam et al., 2010; Turney et al., 2007). These glacier advances occurred during the northern hemisphere Bølling/Allerød interstadial.

\subsubsection{Lake evolution}

The over-deepened nature of the glacially-eroded basins in central Patagonia led to the formation of large proglacial lakes as ice retreat progressed. These lakes initially drained eastward into the Atlantic Ocean because the low-lying structural gap in the Andes $\left(48^{\circ} \mathrm{S}\right)$ was blocked by the PIS. As ice retreat progressed, several of these lakes are thought to have become interconnected as a large regional lake east of the present NPI (Turner et al., 2005; Bell, 2008; Hein et al., 2010; Glasser et al., 2016; Bourgois et al., 2016). The position of ice margins to the west and moraine dams to the east determined the location of low overspill routes and hence controlled the former lake levels (Glasser et al., 2016). The retreating ice margin caused a gradual re-organization of the drainage, leading to a final sudden drainage of the lake into the Pacific as the ice sheet separated and the Río Baker Valley opened up (Turner et al., 2005; Bell, 2008; Hein et al., 2010; Glasser et al., 2016). This forced a $200 \mathrm{~km}$ migration of the water divide, a major re- 
organization of the drainage and released between $160 \mathrm{~km}^{3}$ and $1150 \mathrm{~km}^{3}$ of freshwater into the Pacific Ocean (Glasser et al., 2016; Hein et al., 2010). Therefore, the palaeolake history has implications for understanding of the wider deglacial history of the region, the dynamics of glaciers terminating in such lakes, and the impact of freshwater release on the regional oceanic and climate system in the Pacific. However, the timing and sequence of events relating to the evolution of palaeo-lakes in the LBA/LP basins, is the subject of debate.

Evidence of former lake levels in the form of raised shorelines, deltas and beaches has been documented in the LBA, LP and Chacabuco valleys (Turner et al., 2005; Bell, 2008; Hein et al., 2010; Glasser et al., 2016; Bourgois et al., 2016). The shorelines can be observed as continuous features at the eastern ends of LBA and LP, but become discontinuous toward the interior of the range. The elevations vary within and between each valley, but there appears to be enough coherence to suggest a series of palaeolake levels with an overall tilt toward the east; the tilt and variance are thought to be a consequence of differential isostatic rebound (Turner et al., 2005).

Turner et al. (2005) mapped three distinct shorelines in the LP and LBA valleys, on the basis of which a three-stage lake evolution was inferred. One shoreline mapped at 654-633 $\mathrm{m}$ a.s.1., which is confined to the LP basin, represented an upper lake level which drained eastwards via the Estancia Caracoles channel $(475 \mathrm{~m})$. Retreat of the ice margin exposed a part of Río Baker basin, allowing LP to drain into LBA to create a single lake at a lower elevation of 512-489 $\mathrm{m}$ a.s.1. and 484-390 $\mathrm{m}$ a.s.1. in LP and LBA valley respectively, and leading to the abandonment of the Estancia Caracoles channel. The minimum age for the abandonment of this channel is ca. 13 cal ka BP on the basis of radiocarbon ages from peat within the channel (Turner et al., 2005; Mercer, 1976), but probably closer to $17.3 \pm 1.1 \mathrm{ka}$ on the basis of a cosmogenic ${ }^{10} \mathrm{Be}$ age for the timing of lake drainage (Hein et al., 2010). The above mentioned radiocarbon age is unlikely to be a close minimum age as organic matter is limited and slow to develop in the arid environment east of the Andes. The single pro-glacial lake drained via a channel (near Perito Moreno) eastwards into the Río Deseado and to the Atlantic Ocean. The higher united lake must have formed and drained sometime before ca. 16 cal ka BP, based on the two ${ }^{14} \mathrm{C}$ ages from a kettle hole near Cerro Ataud (Turner et al., 2005) or by ca. $17.3 \mathrm{ka}$, based on the above mentioned ${ }^{10} \mathrm{Be}$ age from a boulder on bedrock ( $350 \mathrm{~m}$ a.s.1.) in the LP valley (Hein et al., 2010). A shoreline recorded at 397-375 $\mathrm{m}$ a.s.1. and 355-305 $\mathrm{m}$ a.s.1. in LP and LBA basins, respectively, provides evidence for a lower united pro-glacial lake. This shoreline is constrained by two ${ }^{10} \mathrm{Be}$ ages from boulders on a delta in Nef Valley $(14.2 \pm 0.6$ and $15.4 \pm 0.6 \mathrm{ka})$, two direct radiocarbon ages obtained from in situ organic material from a kame delta at Río Nef $(12.7 \pm 0.04 \mathrm{cal}$ ka BP $)$ and a lake terrace at Mirador Chile Chico (13.4 $\pm 0.1 \mathrm{cal} \mathrm{ka} \mathrm{BP})$, and several minimum radiocarbon ages from the lake floor (Table 3) (Turner et al., 2005).

Three OSL ages ranging from 12.9 to $10.3 \mathrm{ka}$ have been obtained from deltas above LBA at $\sim 400 \mathrm{~m}$ a.s.1. (Glasser et al., 2016), equivalent to the higher single proglacial lake. However, the ages are significantly younger that the ages for the abandonment of the Estancia Caracoles channel (Turner et al., 2005; Mercer, 1976) and for the drainage 


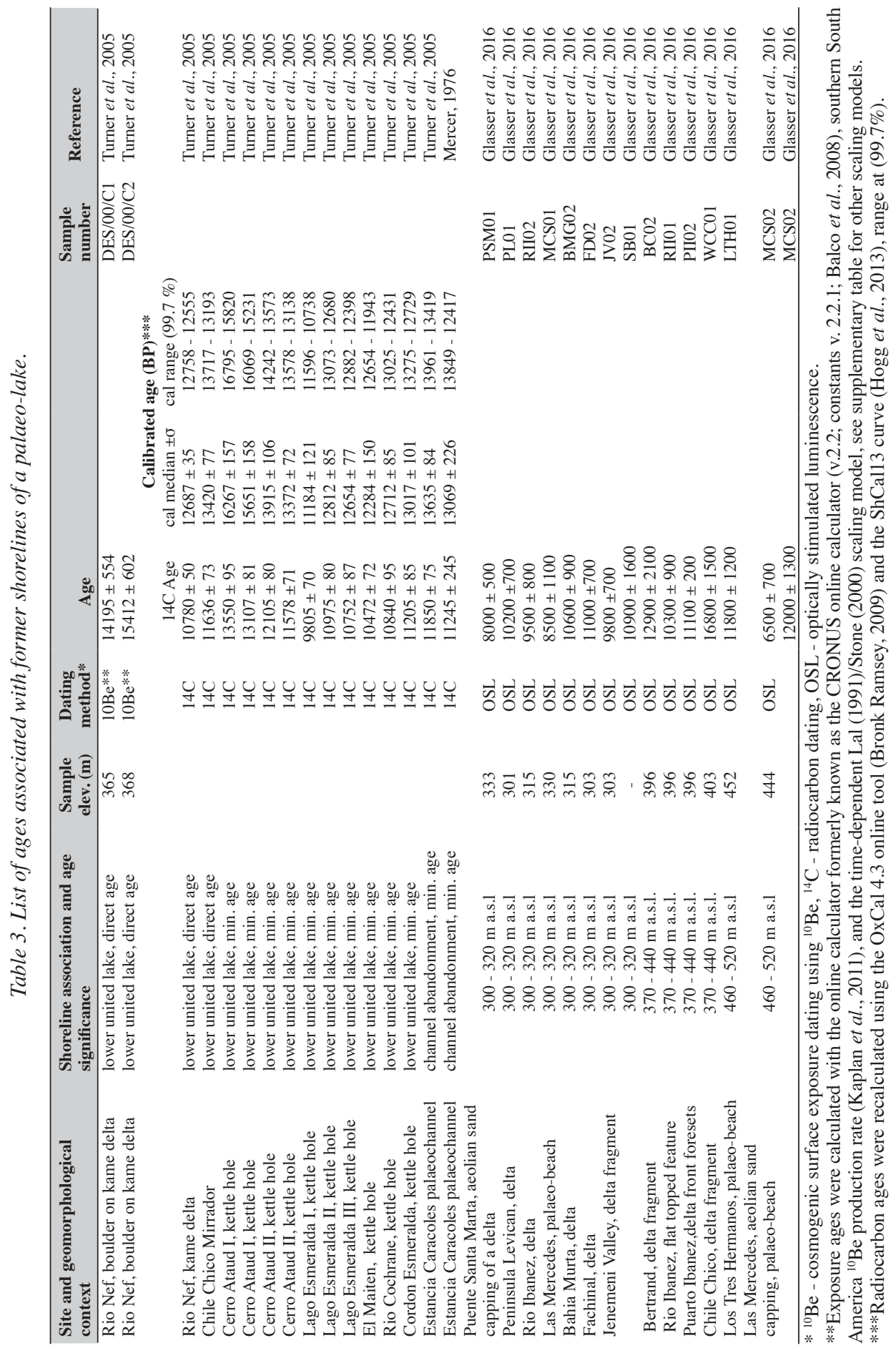


of the higher united lake (Hein et al., 2010). OSL ages from deltas above LBA at 300$315 \mathrm{~m}$ a.s.l., equivalent to the lower united lake, ranged from 11 to $9.5 \mathrm{ka}$ (Glasser et $a l ., 2016$ ), and are also significantly younger than direct and minimum radiocarbon ages for the lower united lake (Turner et al., 2005). The persistence of the lower regional proglacial lake until ca. $8.5 \mathrm{ka}$, proposed on the basis of the two youngest OSL ages from deltas above LBA (Glasser et al., 2016), or $6.7 \mathrm{ka}$ as inferred from the absence of volcanic ash on top of the lowest delta at Fachinal (Bell, 2008), appears at odds with the radiocarbon and cosmogenic nuclide age constraints. It is more likely that the final drainage of the lower pro-glacial lake into the Pacific Ocean occurred at ca. $12.7 \mathrm{ka}$ on the basis of direct radiocarbon ages from the shoreline (Turner et al., 2005). Yet, several interpretations on the exact sequence and timing of events exist (Turner et al., 2005; Bell, 2008; Hein et al., 2010; Glasser et al., 2016; Bourgois et al., 2016) and further work is be required to resolve this.

\subsubsection{Lateglacial palaeoenvironmental and climate records}

Following ice retreat, most records from the eastern side of the Andes indicate an open landscape with sparse scrub-steppe dominated by Poacea, Asteraceae, and Ericaceae under persistent colder and drier conditions at most sites until ca. 14 cal ka BP (Markgraf et al., 2007; de Porras et al., 2012; Iglesias et al., 2016). Steppe taxa such as Plantago and Acaena was often present indicating disturbance and unstable postglacial conditions (de Porras et al., 2012; de Porras et al., 2014; Markgraf et al., 2007; Iglesias et al., 2016). Small abundances of hygrophilous arboreal taxa in records from the eastern side of the Andes were interpreted as a long distance transport from forest refugia along the Pacific coast (Markgraf et al., 2007; de Porras, 2014). Iglesias et al. (2016) inferred $\sim 200 \mathrm{~mm}$ annual precipitation required to support the reconstructed vegetation community $\left(44^{\circ} \mathrm{S} 71^{\circ} \mathrm{W}\right)$. Subsequently, a gradual increase in Nothofagus taxa suggests grass-steppe vegetation with scattered trees and an increase in effective moisture, but still less than modern values (de Porras et al., 2012; Markgraf et al., 2007; de Porras et al., 2014). The pollen record from Lago Los Niños suggests open forest between 14.3-13.2 cal ka BP, with a subsequent trend towards more open landscape and drier conditions until $11.5 \mathrm{cal} \mathrm{ka} \mathrm{BP(Iglesias} \mathrm{et} \mathrm{al.,} \mathrm{2016).} \mathrm{Fluctuations} \mathrm{of} \mathrm{aquatic}$ taxa in pollen records attest for high millennial environmental variability between ca. 14-11 cal ka BP (Markgraf et al., 2007; Villa-Martínez et al., 2012)

Contrary to the above, wetter and colder conditions throughout the Lateglacial period are inferred from the Lago Augusta and Lago Edita pollen record on the basis of arboreal taxa, such as Nothofagus, hygrophilous Fitzroya/Pilgerodendron and Drimys present immediately after the onset of sedimentation and persisting until $11.8 \mathrm{cal} \mathrm{ka} \mathrm{BP}$ (Villa-Martínez et al., 2012; Henríquez et al., 2017). The pollen assemblages reflect patches of evergreen forests in an open landscape, likely a forest refugia in Chacabuco Valley (Henríquez et al., 2017), sustained by the enhanced influence of the SWW at this latitude. A decline in hygrophilous and cold-resistant taxa at ca. $11.8 \mathrm{cal} \mathrm{ka}$ BP is concurrent with an increase in Nothofagus and likely reflects warming and reduced precipitation due to the decreased influence of the SWWs. 


\subsection{Holocene}

\subsubsection{Western Andes}

On the western side, the only evidence of Holocene glacier advances comes from the Rafael Glacier, a large outlet of the NPI. OSL ages from the Tempanos moraines (9.7 ka, 9.3 ka and 5.7 ka) and glacial outwash (7.7 ka and 7.8 ka) suggested that Rafael Glacier was either more extensive between $9.7 \mathrm{ka}$ and $5.7 \mathrm{ka}$, or advanced multiple times during this time period (Harrison et al., 2012). However, non-climatic factors related to calving dynamics may have driven the Holocene fluctuations of Rafael Glacier. Previous sedimentological work demonstrated the complex composition of these moraines, resulting from sediment reworking by a glacier re-advance into its former proglacial area (Glasser et al., 2006). Holocene advances of the Rafael Glacier correlate with short term variations in offshore terrigenous sediment input at 10.1-9.1 ka and 7.8-6.5 ka, probably indicating glacier re-advances (Siani et al., 2010). Palaeoenvironmental archives, however, indicate warmer $\left(\sim 1^{\circ}\right.$ to $2^{\circ} \mathrm{C}$ above present mean temperature) and drier conditions during the early Holocene, as suggested by forests in the Chonos Archipelago dominated by Tepualia and Weinmannia between 12.4-6.7 ka (Haberle and Bennett, 2004). Palynological analysis of a marine core recovered off the Taitao Peninsula $46^{\circ}$ S (MD073088) showed an increase in heliophytic taxa, such as Myrtace $a$ and Tepualia, from 11.5 to $7.4 \mathrm{ka}$, indicating the warmest and driest conditions of the Holocene (Montade et al., 2013). This is further supported by a chironomid record from Laguna Stibnite which suggested conditions drier than today between 10.5-7.2 cal ka BP (Massaferro and Brooks, 2002).

With the exception of one OSL date from the Tempanos moraines (see above), no moraines directly dated to the mid-Holocene have been reported. Sedimentological and geochemical analysis of two fjord sediment cores suggested that Gualas Glacier advanced towards the Golfo Elefantes shore between ca. $4 \mathrm{ka}$ and $0.8 \mathrm{ka}$ (Bertrand et $a l ., 2012)$. The chironomid record from Laguna Stibnite suggests a trend towards wetter conditions during the mid-Holocene indicating intermediate precipitation between 7.25.2 cal ka BP and higher precipitation between 5.2-2.4 cal ka BP(Massaferro and Brooks, 2002). Slightly cooler and wetter conditions were also inferred from an increase in arboreal taxa, such as Pilgerodendron, in the marine pollen record from ca. 7.4 cal ka BP (Montade et al., 2013).

\subsubsection{Eastern Andes}

The Fachinal moraines were deposited on top of a raised delta above LBA and have

${ }^{10} \mathrm{Be}$ and ${ }^{36} \mathrm{Cl}$ ages of $8.9 \mathrm{ka}$ (peak, inner moraine) and $10.9 \mathrm{ka}$ (peak, outer moraine) (Douglass et al., 2005). The ages, including repeat measurements, in particular for the outer moraines, show a considerable scatter (Fig. 6). ${ }^{10} \mathrm{Be}$ ages from moraines east of the NPI (Leones and Nef valleys, Lago Negro, Lago Bertrand) might represent early Holocene advances (see section 4.2.2.1) (Glasser et al., 2012), correlative to the outer Fachinal moraines.

Palaeoenvironmental records suggest a drier and warmer period in the early Holocene. At ca. $11 \mathrm{ka}$, most records detected an increase in the frequency and magnitude 


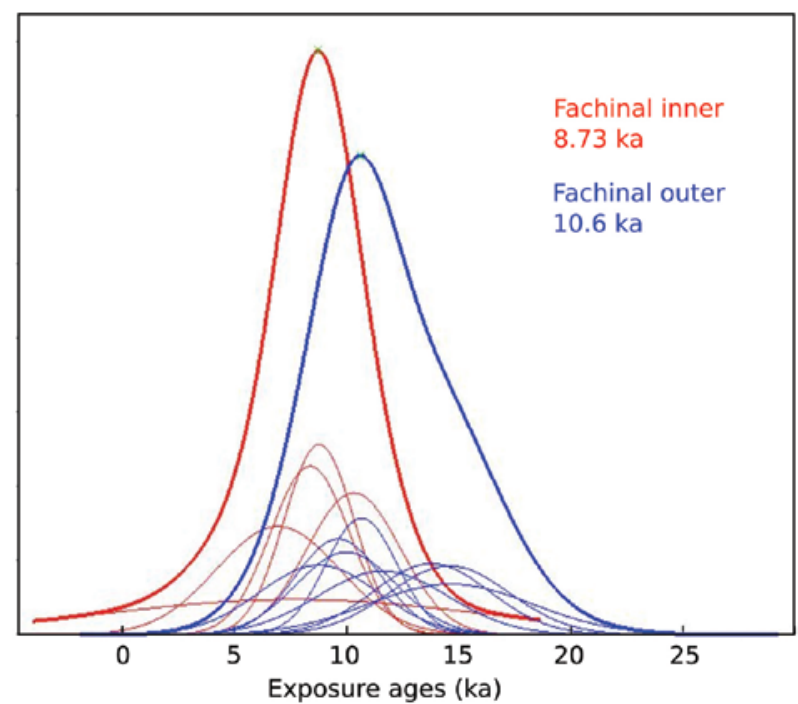

Figure 6. Camel plots summarising distribution of ${ }^{10} \mathrm{Be}$ ages for the inner and outer Fachinal moraines, outliers identified in the original publications were removed. Including re-calculated

${ }^{36} \mathrm{Cl}$ ages (Douglass et al., 2005) in the probability distribution (not shown) makes the peak age of the outer Fachinal moraine slightly younger $(9.73 \mathrm{ka})$. Thin lines represent individual Gaussian probability distributions for ${ }^{10} \mathrm{Be}$ ages with $1 \sigma$ internal error; thick line represents the sum of the individual probability distributions.

of fires (de Porras et al., 2012; de Porras et al., 2014; Markgraf et al., 2007; VillaMartínez et al., 2012), accompanied by a sudden change from aquatic to a dominance of marsh/bog taxa (de Porras et al., 2012), including a short-lived drying of a fen at Mallín Pollux (Markgraf et al., 2007). However, the concurrent expansion of Nothofagus forest suggests these changes represent an increase in effective moisture, but below modern values, and summers that were drier and/or warmer than present (de Porras et al., 2012; de Porras et al., 2014; Markgraf et al., 2007). The palynological record from the southern side of Lago San Martin is characterized by dominance of Poaceae- Ephedra Chenopodiaceaea taxa between 11.3-9.5 cal ka BP. This pollen assemblage is analogous to modern dwarf-shrub steppe and was interpreted to represent precipitation lower than today, likely around $200 \mathrm{~mm} \mathrm{a}^{-1}$ (Bamonte and Mancini, 2011). The increased frequency of fires, a peak in laminated carbonate deposition, decline of hygrophilous and coldresistant taxa and the increase of Nothofagus taxa at Lago Augusta at ca. $11.8 \mathrm{cal} \mathrm{ka} \mathrm{BP}$ was interpreted as a temperature increase and precipitation decrease, driven by a shift in the SWWs (Villa-Martínez et al., 2012). A major transgression was documented at Lago Cardiel during early Holocene ca. 11.8 cal ka BP (Gilli et al., 2005), attributed to easterly moisture advection to the extra-Andean region due to decreased SWW influence, which would support decreased precipitation within the Andes.

The cosmogenic ${ }^{10} \mathrm{Be}$ ages on moraines in the Río Tranquilo valley, indicate that an outlet glacier of the San Lorenzo ice cap advanced at ca. $5.5 \mathrm{ka}$ (Sagredo et al., 2016). Three OSL ages $(2.6 \pm 0.2 \mathrm{ka}, 2.4 \pm 0.5 \mathrm{ka}$ and $3.3 \pm 0.9 \mathrm{ka})$ were obtained from glacio- 
lacustrine sediments and a section in a terminal moraine of the Leon Glacier (Harrison et al., 2008). The OSL ages are, however, inconsistent with ${ }^{10} \mathrm{Be}$ ages obtained from the terminal moraine (1.1 ka and $0.9 \mathrm{ka}$ ) (Harrison et al., 2008). Several records suggest wetter and/or colder conditions during the mid-Holocene. From 8-3 cal ka BP the Lake Shaman record suggests the highest effective moisture for the whole record (de Porras et al., 2012). A shift to colder, periglacial conditions between 7.4-6.5 cal ka BP was inferred from sediment stratigraphy and a pollen record at a high altitude site at $\sim 47^{\circ} \mathrm{S}$, followed by drier temperate conditions until $3.7 \mathrm{cal} \mathrm{ka} \mathrm{BP}$, and a subsequent shift to more humid, temperate conditions (McCulloch et al., 2016). Similarly, a pollen record from Lago San Martin $\sim 49^{\circ} \mathrm{S}$ indicated a decrease in moisture levels $\left(<300 \mathrm{~mm} \mathrm{a}^{-1}\right)$ between 8-3 cal ka BP (Bamonte and Mancini, 2011). At other sites, no major changes in the pollen record were observed once the closed Nothofagus forest established (VillaMartínez et al., 2012; Markgraf et al., 2007).

There is evidence from both sides of the Andes for Lateglacial/early Holocene advances in central Patagonia (Glasser et al., 2012; Harrison et al., 2012; Douglass et al., 2005). Variations in the terrigenous sediment record, interpreted as a proxy for glacier activity, supports early Holocene (10 - $9 \mathrm{ka}$ ) glacier expansion (Siani et al., 2010). These glacier advances occurred despite the drier and warmer conditions inferred from the palaeoenvironmental proxies. It also contrasts with well-dated chronologies from southern Patagonia, where there was extensive recession of the Upsala Glacier from its Lateglacial maximum to within the present-day limit by $\sim 9.2 \mathrm{ka}$ (Kaplan et al., 2016; Strelin et al., 2014; Strelin et al., 2011). The SPI outlet glaciers were most extensive between 6.1-4.5 ka (Kaplan et al., 2016; Strelin et al., 2014; Strelin et al., 2011). Model simulations suggested a northward shift of low level SWWs at and before $9 \mathrm{ka}$, leading to substantial precipitation increases on the western side of Andes and at high elevation north of $49^{\circ} \mathrm{S}$ (Pollock and Bush, 2013).

\section{Discussion and Conclusions}

\subsection{Local LGM}

The LGM is only constrained chronologically at LBA and LP where the Fenix and Río Blanco ice limits represent advances contemporaneous with the global LGM. However, there exists a growing body of evidence from elsewhere in Patagonia and New Zealand to suggest that glaciers reached their maxima earlier in the last glacial cycle, during MIS 3 when southern insolation was more favourable (García et al., in review). The MIS 3 advances are coeval with a peak in the EPICA Dome $\mathrm{C}$ dust record between ca. 31-37 ka (Lambert et al., 2008). Such dust peaks have previously been correlated with glacier advances in southern Patagonia (Sugden et al., 2009). There is also a trend of decreasing sea surface temperatures in the marine offshore record, near the coast of Chile $\left(41^{\circ} \mathrm{S}\right)$, during the late MIS 3 (Kaiser et al., 2005; Lamy et al., 2004). The apparent absence of an MIS 3 glacier advance in central Patagonia (with the exception of some tentative evidence; Smedley et al., 2016; Hein et al., 2010) is therefore puzzling. The absence of this signal in central Patagonia might be due to: 1) lack of discovery 2) the large LBA/LP outlet glaciers failing to respond to this climate signal; 3) calving into 
large proglacial lakes that might have decoupled these outlet glaciers from climate; 4) pre-LGM advances were later obliterated by a more extensive LGM advance; or 5) preLGM moraines were removed by focused meltwater erosion as a consequence of the over-deepened nature of the big glacial basins of central Patagonia (e.g. Hein et al., 2017). Determining the geographic extent of the MIS 3 advance and the global LGM should be a priority for resolving the drivers of southern hemisphere mountain glaciation. Thus, in central and, in particular, northern Patagonia, there is a need to derive detailed glacial chronologies for what are assumed to be LGM and pre-LGM moraines. Ideally, moraines should be targeted for dating in valleys where complication by points 3 ) and 5) can be avoided. Robust chronologies are required to confidently resolve the occurrence, or absence, of the MIS 3 advance in central Patagonia, to determine its geographic extent relative to the global LGM limits, and to explore the drivers of southern hemisphere glaciation through modelling.

\subsection{Lateglacial}

The Lateglacial ice marginal positions are poorly constrained and the occurrence of the ACR and/or YD is equivocal in central Patagonia. Only at one site, the Tranquilo Glacier, moraines have been dated to the ACR (E. Sagredo, personal communication, 2017). The offshore pollen record is the only palaeoenvironmental proxy, which firmly shows a vegetation change indicative of cooling coeval with the ACR (Montade et al., 2013). Other palaeovegetation proxies, however, do not indicate any significant vegetation changes from which cooling contemporaneous with either the ACR or YD may be inferred. An exception to this is a chironomid record, from which minor cooling at the time of YD was inferred (Massaferro and Brooks, 2002). Proxies from the eastern side of the Andes show high variability in effective moisture during the Lateglacial (15-11 ka), which together with the degree of insensitivity of proxies to minor oscillations in temperature might have masked any less pronounced cooling coeval with either the ACR or YD. Moraines deposited by the eastern outlet glaciers of the NPI, were dated at the Lateglacial/Holocene transition, which might represent YD readvances or stillstands (Glasser et al., 2012). Obtaining minimum and/or maximum radiocarbon ages for some of these moraines would provide further chronological control needed to improve dating resolution. Obtaining chronological constrains from undated, likely Lateglacial, moraines on the western side of the Andes, would fill the spatial and temporal gap and help to evaluate the relative extent of glaciers during ACR and YD. On the eastern side of the Andes moraines unaffected by regional lake inundation should be targeted for dating. The existence of the regional pro-glacial lake implies substantial ice mass and ice margin stabilization to maintain the ice damn. The lake was probably in existence since the retreat of ice from the position of the Menucos moraines and the youngest Río Blanco moraines at LP. The inconsistency in the interpretation of radiocarbon and OSL ages from shorelines renders the history of the lake open to debate. Resolving the lake history is important for understanding the wider deglacial history, especially since such lakes may have decoupled glacier response from climate by invoking calving dynamics. 


\subsection{Holocene}

Much of the early work on Holocene glacial advances often relied on single minimum/maximum radiocarbon age from a given locality (see Glasser et al., 2004). It is only in last decade and a half that a wider range of dating techniques such as OSL, more robust radiocarbon chronologies, and cosmogenic nuclide dating have been applied to date Holocene glacial advances in Patagonia (e.g. Strelin et al., 2011, 2014; Kaplan et al., 2016; Harrison et al., 2012). Yet, evidence for Holocene glacier advances in central Patagonia remains sparse and poorly constrained. The available evidence suggests that the glaciers in central Patagonia advanced or stabilised at the Lateglacial/Holocene transition, while the contemporary palaeoenvironmental proxies revealed warm and dry conditions throughout central Patagonia. The explanation for this is unclear, within dating uncertainties, these advances might represent Lateglacial events. Alternatively, more easterly penetration of the SWWs and precipitation due to a diminishing NPI could have promoting advances of glaciers in the higher mountains east of the NPI as suggested by modelling experiments (Hubbard et al., 2005). There is far less evidence for moraines deposited during the mid-Holocene, with only one moraine (Tranquilo valley) directly dated (Sagredo et al., 2016), when palaeoenvironmental records showed colder and/or wetter conditions. The duration of these climatic changes evident from palaeoenvironmental proxies varied between sites. The timing and pattern of Holocene glacial advances in central Patagonia remains elusive. Improvements in cosmogenic nuclide dating methods have enabled increasingly younger surfaces to be dated. In combination with bracketing radiocarbon ages, this approach would provide robust chronological control in order to determine the pattern of Holocene glacier advances.

\section{Acknowledgements}

We thank the UK Natural Environment Research Council and University of Edinburgh for Monika Mendelova's Ph.D. studentship.

\section{References}

Ackert, R., Becker, R.A., Singer, B.S., Kurz, M.D., Caffee, M.W., Mickelson, D.M. 2008. Patagonian Glacier Response during the Late Glacial - Holocene Transition. Science 321, 5887, 392-396. https://doi.org/10.1126/science.1157215.

Aravena, J.C., Luckman, B.H. 2009. Spatio-temporal rainfall patterns in 542 Southern South America. International Journal of Climatology 29, 2106-2120. http://doi.org/10.1002/joc.1761

Balco, G., Stone, J.O., Lifton, N.A., Dunai, T.J. 2008. A complete and easily accessible means of calculating surface exposure ages or erosion rates from ${ }^{10} \mathrm{Be}$ and ${ }^{26} \mathrm{Al}$ measurements. Quaternary Geochronology 3 (3), 174-195. http://doi.org/10.1016/j.quageo.2007.12.001.

Bamonte, F.P., Mancini, M.V. 2011. Palaeoenvironmental changes since Pleistocene-Holocene transition: Pollen analysis from a wetland in southwestern Patagonia (Argentina). Review of Palaeobotany and Palynology 165 (1-2), 103-110. http://doi.org/10.1016/j. revpalbo.2011.02.003.

Bell, C.M. 2008. Punctuated drainage of an ice-damned Quaternary lake in Southern South America. Geografiska Annaler 90A (1), 1-17. http://doi.org/10.1111/j.1468-0459.2008.00330.x. 
Bennett, K.D., Haberle, S.G., Lumley, S.H. 2000. The Last Glacial-Holocene Transition in Southern Chile. Science 290, 325-328. https://doi.org/10.1126/science.290.5490.325.

Bertrand, S., Hughen, K.A., Lamy, F., Stuut, J.B.W., Torrejón, F., Lange, C.B. 2012. Precipitation as the main driver of Neoglacial fluctuations of Gualas glacier, Northern Patagonian Icefield. Climate of the Past 8 (2), 519-534. http://doi.org/10.5194/cp-8-519-2012.

Boex, J., Fogwill, C., Harrison, S., Glasser, N.F., Hein, A., Schnabel, C., Xu, S. 2013. Rapid thinning of the late Pleistocene Patagonian Ice Sheet followed migration of the Southern Westerlies. Scientific Reports 3, 2118. http://doi.org/10.1038/srep02118.

Bourgois, J., Cisternas, M.E., Braucher, R., Bourlès, D., Frutos, J. 2016. Geomorphic Records along the General Carrera (Chile)-Buenos Aires (Argentina) Glacial Lake (46 ${ }^{\circ}-48^{\circ} \mathrm{S}$ ), Climate Inferences, and Glacial Rebound for the Past 7-9 ka. The Journal of Geology 124 (1), 27-53. http://doi.org/10.1086/687551

Bronk Ramsey, C. 2009. Bayesian Analysis of Radiocarbon Dates. Radiocarbon 51 (1), 337-360. https://doi.org/10.1017/S0033822200033865.

Caldenius, C.R.C. 1932. Las glaciaciones cuaternarias en la Patagonia y Tierra del Fuego. Geografiska Annaler 14, 1-164. https://www.jstor.org/stable/pdf/519583.pdf.

Carrivick, J.L., Davies, B.J., James, W.H.M., Quincey, D.J., Glasser, N.F. 2016. Distributed ice thickness and glacier volume in southern South America. Global and Planetary Change 146, 122-132. http://doi.org/10.1016/j.gloplacha.2016.09.010.

Clapperton, C.M. 1993. Nature of environmental changes in South America at the Last Glacial Maximum. Palaeogeography, Palaeoclimatology, Palaeoecology 101 (3-4), 189-208. https://doi.org/10.1016/0031-0182(93)90012-8.

Clark, P.U., Dyke, A.S., Shakun, J.D., Carlson, A.E., Clark, J., Wohlfarth, B., Mitrovica, J.X., Hostetler, S.W., McCabe, A.M. 2009. The Last Glacial Maximum. Science 325, 710-714. https://doi.org/10.1126/science.1172873.

Darvill, C.M., Bentley, M.J., Stokes, C.R., Hein, A.S., Rodés, Á. 2015. Extensive MIS 3 glaciation in southernmost Patagonia revealed by cosmogenic nuclide dating of outwash sediments. Earth and Planetary Science Letters 429, 157-169. http://doi.org/10.1016/j.eps1.2015.07.030.

Davies, B.J., Glasser, N.F. 2012. Accelerating shrinkage of Patagonian glaciers from the Little Ice Age ( AD 1870) to 2011. Journal of Glaciology 58 1063-1084. https://doi. org/10.3189/2012JoG12J026.

Denton, G.H., Lowell, T. V, Heusser, C.J., Schluchter, C., Andersen, B.G., Heusser, L.E., Moreno, P.I., Marchant, D.R. 1999. Geomorphology, stratigraphy, and radiocarbon chronology of LlanquihueDrift in the area of the Southern Lake District, Seno Reloncaví, and Isla Grande de Chiloé, Chile. Geografiska Annaler Series A Physical Geography 81A (2), 167-229. http:// doi.org/10.1111/1468-0459.00057.

de Porras, M.E., Maldonado, A., Abarzúa, A.M., Cárdenas, M.L., Francois, J.P., Martel-Cea, A., Stern, C.R., Méndez, C., Reyes, O. 2012. Postglacial vegetation, fire and climate dynamics at Central Chilean Patagonia (Lake Shaman, $44^{\circ} \mathrm{S}$ ). Quaternary Science Reviews 50, 71-85. http://doi.org/10.1016/j.quascirev.2012.06.015.

de Porras, M.E., Maldonado, A., Quintana, F.A., Martel-Cea, A., Reyes, O., Méndez, C. 2014. Environmental and climatic changes in central Chilean Patagonia since the Late Glacial (Mallín El Embudo, 44º S). Climate of the Past 10 (3), 1063-1078. http://doi.org/10.5194/ cp-10-1063-2014.

Doughty, A.M., Schaefer, J.M., Putnam, A.E., Denton, G.H., Kaplan, M.R., Barrell, D.J.A., Andersen, B.G., Kelley, S.E., Finkel, R.C., Schwartz, R. 2015. Mismatch of glacier extent and summer insolation in Southern Hemisphere mid-latitudes. Geology 43 (5), 407-410. https://doi.org/10.1130/G36477.1.

Douglass, D., Singer, B., Kaplan, M., Mickelson, D., Caffee, M. 2006. Cosmogenic nuclide surface exposure dating of boulders on last-glacial and late-glacial moraines, Lago Buenos Aires, 
Argentina: Interpretive strategies and paleoclimate implications. Quaternary Geochronology 1 (1), 43-58. http://doi.org/10.1016/j.quageo.2006.06.001.

Douglass, D.C., Bockheim, J.G. 2006. Soil-forming rates and processes on Quaternary moraines near Lago Buenos Aires, Argentina. Quaternary Research 65 (2), 293-307. http://doi. org/10.1016/j.yqres.2005.08.027.

Douglass, D.C., Singer, B.S., Kaplan, M.R., Ackert, R.P., Mickelson, D.M., Caffee, M.W. 2005. Evidence of early Holocene glacial advances in southern South America from cosmogenic surface-exposure dating. Geology 33 (3), 237-240. https://doi.org/10.1130/G21144.1.

Dowdeswell, J.A., Dowdeswell, E.K., Rodrigo, C., Diaz, J. 2016. Assemblage of glacial and related landforms in the fjords of southern Chile. In: J.A. Dowdeswell, M. Canals, M. Jakobsson, J. Todd, E.K. Dowdeswell, K.A. Hogan (Eds.), Geological Society, London, Memoirs: 131-134. http://www.submarineglacialatlas.com/authors/examples/assemblage/assemblage1oct.pdf.

Dowdeswell, J.A., Vásquez, M. 2013. Submarine landforms in the fjords of southern Chile: Implications for glacimarine processes and sedimentation in a mild glacierinfluenced environment. Quaternary Science Reviews 64, 1-19. http://doi.org/10.1016/j. quascirev.2012.12.003.

Fernandez, R., Anderson, J., Bertrand, S., Wellner, J. 2012. Gualas Glacier sedimentary record of climate and environmental change, Golfo Elefantes, Western Patagonia $\left(46.5^{\circ} \mathrm{S}\right)$. Holocene 22 (4), 451-463. https://doi.org/10.1177/0959683611425545.

Fogwill, C.J., Kubik, P.W. 2005. A glacial stage spanning the Antarctic Cold Reversal in Torres del Paine $\left(51^{\circ} \mathrm{S}\right)$, Chile, based on preliminary cosmogenic exposure ages. Geografiska Annaler, Series A: Physical Geography 87 (2), 403-408. http://doi.org/10.1111/j.04353676.2005.00266.x.

García, J.L., Kaplan, M.R., Hall, B.L., Schaefer, J.M., Vega, R.M., Schwartz, R., Finkel, R. 2012. Glacier expansion in southern Patagonia throughout the Antarctic cold reversal. Geology 40 (9), 859-862. https://doi.org/10.1130/G33164.1.

García, J.L., Hall, B.L., Kaplan, M.R., Vega, R.M., Strelin, J.A. 2014. Glacial geomorphology of the Torres del Paine region (southern Patagonia): Implications for glaciation, deglaciation and paleolake history. Geomorphology 204, 599-616. http://doi.org/10.1016/j. geomorph.2013.08.036.

Garreaud, R., López, P., Minvielle, M., Rojas, M. 2013. Large-scale control on the Patagonian climate. Journal of Climate 26 (1), 215-230. http://doi.org/10.1175/JCLI-D-12-00001.1.

Garreaud, R.D. 2009. The Andes climate and weather. Advances in Geosciences 22, 3-11. Doi:10.5194 / ADGEO-22-3-2009.

Garreaud, R.D., Vuille, M., Compagnucci, R., Marengo, J. 2009. Present-day South American climate. Palaeogeography, Palaeoclimatology, Palaeoecology 281 (3-4), 180-195. http://doi. org/10.1016/j.palaeo.2007.10.032.

Gilli, A., Anselmetti, F.S., Ariztegui, D., Beres, M., McKenzie, J.A., Markgraf, V. 2005. Seismic stratigraphy, buried beach ridges and contourite drifts: the Late Quaternary history of the closed Lago Cardiel basin, Argentina ( $\left.49^{\circ} \mathrm{S}\right)$. Sedimentology 52, 1, 1-23. http://doi. org/10.1111/j.1365-3091.2004.00677.x.

Glasser, N.F., Ghiglione, M.C. 2009. Structural, tectonic and glaciological controls on the evolution of fjord landscapes. Geomorphology 105, 3-4, 291-302. http://doi.org/10.1016/j. geomorph.2008.10.007.

Glasser, N.F., Harrison, S., Ivy-Ochs, S., Duller, G.A.T., Kubik, P.W. 2006. Evidence from the Rio Bayo valley on the extent of the North Patagonian Icefield during the Late Pleistocene-Holocene transition. Quaternary Research 65, 1, 70-77. Doi:http://doi.org/10.1016/j.yqres.2005.09.002.

Glasser, N.F., Harrison, S., Schnabel, C., Fabel, D., Jansson, K.N. 2012. Younger Dryas and early Holocene age glacier advances in Patagonia. Quaternary Science Reviews 58, 7-17. http:// doi.org/10.1016/j.quascirev.2012.10.011. 
Glasser, N.F., Harrison, S., Winchester, V., Aniya, M. 2004. Late Pleistocene and Holocene palaeoclimate and glacier fluctuations in Patagonia. Global and Planetary Change 43 (1-2), 79101. http://doi.org/10.1016/j.gloplacha.2004.03.002.

Glasser, N.F., Jansson, K., Mitchell, W.A., Harrison, S. 2006. The geomorphology and sedimentology of the 'Témpanos' moraine at Laguna San Rafael, Chile. Journal of Quaternary Science 21 (6), 629-643. http://doi.org/10.1002/jqs.1002.

Glasser, N.F., Jansson, K.N. 2005. Fast-flowing outlet glaciers of the Last Glacial Maximum Patagonian Icefield. Quaternary Research 63 (2), 206-211. http://doi.org/10.1016/j. yqres.2004.11.002.

Glasser, N.F., Jansson, K.N., Duller, G.A.T., Singarayer, J., Holloway, M., Harrison, S. 2016. Glacial lake drainage in Patagonia (13-8 kyr) and response of the adjacent Pacific Ocean. Scientific reports 6, 21064. http://doi.org/10.1038/srep21064.

Glasser, N.F., Jansson, K.N., Goodfellow, B.W., de Angelis, H., Rodnight, H., Rood, D.H. 2011. Cosmogenic nuclide exposure ages for moraines in the Lago San Martin Valley, Argentina. Quaternary Research 75 (3), 636-646. http://doi.org/10.1016/j.yqres.2010.11.005.

Glasser, N.F., Jansson, K.N., Harrison, S., Kleman, J. 2008. The glacial geomorphology and Pleistocene history of South America between $38^{\circ} \mathrm{S}$ and $56^{\circ} \mathrm{S}$. Quaternary Science Reviews 27 (3-4), 365-390. http://doi.org/10.1016/j.quascirev.2007.11.011.

Gutiérrez, F., Gioncada, A., González Ferran, O., Lahsen, A., Mazzuoli, R. 2005. The Hudson Volcano and surrounding monogenetic centres (Chilean Patagonia): An example of volcanism associated with ridge-trench collision environment. Journal of Volcanology and Geothermal Research 145 (3-4), 207-233. http://doi.org/10.1016/j.jvolgeores.2005.01.014.

Haberle, S.G., Bennett, K.D. 2004. Postglacial formation and dynamics of North Patagonian Rainforest in the Chonos Archipelago, Southern Chile. Quaternary Science Reviews 23, 2433-2452. http://doi.org/10.1016/j.quascirev.2004.03.001.

Harrison, S., Glasser, N., Winchester, V., Haresign, E., Warren, C., Duller, G.A.T., Bailey, R., Ivy-Ochs, S., Jansson, K., Kubik, P. 2008. Glaciar León, Chilean Patagonia: lateHolocene chronology and geomorphology. The Holocene 18 (4), 643-652. https://doi. org/10.1177/0959683607086771.

Harrison, S. 2004. The Pleistocene Glaciations of Chile. Developments in Quaternary Sciences 2, part C, 89-103. https://doi.org/10.1016/S1571-0866(04)80115-5.

Harrison, S., Glasser, N.F., Duller, G.A.T., Jansson, K.N. 2012. Early and mid-Holocene age for the Tempanos moraines, Laguna San Rafael, Patagonian Chile. Quaternary Science Reviews 31, 82-92. http://doi.org/10.1016/j.quascirev.2011.10.015.

Hein, A.S., Cogez, A., Darvill, C.M., Mendelova, M., Kaplan, M.R., Herman, F., Dunai, T.J., Norton, K.,Xu, S., Christl, M., Rodés, Á. 2017. Regional mid-Pleistocene glaciation in central Patagonia. Quaternary Science Reviews 164, 77-94. https://doi.org/10.1016/j.quascirev.2017.03.023.

Hein, A.S., Hulton, N.R.J., Dunai, T.J., Schnabel, C., Kaplan, M.R., Naylor, M., Xu, S. 2009. Middle Pleistocene glaciation in Patagonia dated by cosmogenic-nuclide measurements on outwash gravels. Earth and Planetary Science Letters 286 (1-2), 184-197. http://doi. org/10.1016/j.epsl.2009.06.026.

Hein, A.S., Hulton, N.R.J., Dunai, T.J., Sugden, D.E., Kaplan, M.R., Xu, S. 2010. The chronology of the Last Glacial Maximum and deglacial events in central Argentine Patagonia. Quaternary Science Reviews 29 (9-10), 1212-1227. http://doi.org/10.1016/j.quascirev.2010.01.020.

Henríquez, W.I., Villa-Martínez, R., Vilanova, I., De Pol-Holz, R., Moreno, P. 2017. The Last Glacial Termination on the eastern flank of the central Patagonian Andes $\left(47^{\circ} \mathrm{S}\right)$. Climate of the Past Discussions 13, 879-895. http://doi.org/10.5194/cp-13-879-2017.

Heusser, C.J. 2002. On glaciation of the southern Andes with special reference to the Peninsula de Taitao and adjacent Andean cordillera (46 30's). Journal of South American Earth Sciences 15 (5), 577-589. http://doi.org/10.1016/S0895-9811(02)00076-7. 
Hogg, A.G., Hua, Q., Blackwell, P.G., Niu, M., Buck, C.E., Guilderson, T.P., Heaton, T.J., Palmer, J.G., Reimer, P.J., Reimer, R.W., Turney, C.S.M., Zimmerman, S.R.H. 2013. SHCal13 Southern Hemisphere Calibration, 0-50,000 Years cal BP. Radiocarbon 55 (4), 1889-1903. https://doi.org/10.2458/azu_js_rc.55.16783.

Hubbard, A., Hein, A.S., Kaplan, M.R., Hulton, N.R.J., Glasser, N.F. 2005. A Modelling Reconstruction Of The Last Glacial Maximum Ice Sheet And Its Deglaciation In The Vicinity Of The Northern Patagonian Icefield, South America. Geografiska Annaler, Series A: Physical Geography 87 (2), 375-391. http://doi.org/10.1111/j.0435-3676.2005.00264.x.

Iglesias, V., Markgraf, V., Whitlock, C. 2016. 17,000 years of vegetation, fire and climate change in the eastern foothills of the Andes (lat. $44^{\circ} \mathrm{S}$ ). Palaeogeography, Palaeoclimatology, Palaeoecology 457, 195-208. http://doi.org/10.1016/j.palaeo.2016.06.008.

Kaiser, J., Lamy, F., Hebbeln, D. 2005. A 70-kyr sea surface temperature record off southern Chile (Ocean Drilling Program Site 1233). Paleoceanography 20 (4), PA4009. http://doi. org/10.1029/2005PA001146.

Kaplan, M.R., Ackert, R.P., Singer, B.S., Douglass, D.C., Kurz, M.D. 2004. Cosmogenic nuclide chronology of millennial-scale glacial advances during O-isotope stage 2 in Patagonia. Bulletin of the Geological Society of America 116 (3-4), 308-321 . https://doi.org/10.1130/B25178.1.

Kaplan, M.R., Moreno, P.I., Rojas, M. 2008a. Glacial dynamics in southernmost South America during Marine Isotope Stage 5e to the Younger Dryas chron: a brief review with a focus on cosmogenic nuclide measurements. Journal of Quaternary Science 23 (6-7), 649-658. http:// doi.org/10.1002/jqs.1209.

Kaplan, M.R., Fogwill, C.J., Sugden, D.E., Hulton, N.R.J., Kubik, P.W., Freeman, S.P.H.T. 2008b. Southern Patagonian glacial chronology for the Last Glacial period and implications for Southern Ocean climate. Quaternary Science Reviews 27 (3-4), 284-294. http://doi. org/10.1016/j.quascirev.2007.09.013.

Kaplan, M.R., Schaefer, J.M., Denton, G.H., Barrell, D.J., Chinn, T.J., Putnam, A.E., Andersen, B.G., Finkel, R.C., Schwartz, R., Doughty, A.M. 2010. Glacier retreat in New Zealand during the Younger Dryas stadial. Nature 467, 194-197. http://doi.org/10.1038/nature09313.

Kaplan, M.R., Schaefer, J.M., Denton, G.H., Doughty, A.M., Barrell, D.J.A., Chinn, T.J.H., Putnam, A.E., Andersen, B.G., Mackintosh, A., Finkel, R.C., Schwartz, R., Anderson, B. 2013. The anatomy of long-term warming since $15 \mathrm{ka}$ in New Zealand based on net glacier snowline rise. Geology 41 (8), 887-890. https://doi.org/10.1130/G34288.1.

Kaplan, M.R., Schaefer, J.M., Strelin, J.A., Denton, G.H., Anderson, R.F., Vandergoes, M.J., Finkel, R.C., Schwartz, R., Travis, S.G., Garcia, J.L., Martini, M.A., Nielsen, S.H.H. 2016. Patagonian and southern South Atlantic view of Holocene climate. Quaternary Science Reviews 141, 112-125. http://doi.org/10.1016/j.quascirev.2016.03.014.

Kaplan, M.R., Strelin, J.A., Schaefer, J.M., Denton, G.H., Finkel, R.C., Schwartz, R., Putnam, A.E., Vandergoes, M.J., Goehring, B.M., Travis, S.G. 2011. In-situ cosmogenic ${ }^{10}$ Be production rate at Lago Argentino, Patagonia: Implications for late-glacial climate chronology. Earth and Planetary Science Letters 309 (1-2), 21-32. http://doi.org/10.1016/j.epsl.2011.06.018.

Kelley, S.E., Kaplan, M.R., Schaefer, J.M., Andersen, B.G., Barrell, D.J.A., Putnam,A.E., Denton, G.H., Schwartz, R., Finkel, R.C., Doughty, A.M. 2014. High-precision ${ }^{10}$ Be chronology of moraines in the Southern Alps indicates synchronous cooling in Antarctica and New Zealand 42,000 years ago. Earth and Planetary Science Letters 405, 194-206. http://doi.org/10.1016/j.epsl.2014.07.031.

Lagabrielle, Y., Suárez,M., Rossello, E.A.,Hérail, G., Martinod, J., Régnier, M., de la Cruz, R. 2004. Neogene to Quaternary tectonic evolution of the Patagonian Andes at the latitude of the Chile Triple Junction. Tectonophysics 385, 211-241. http://doi.org/10.1016/j.tecto.2004.04.023.

Lambert, F., Delmonte, B., Petit, J.R., Bigler, M., Kaufmann, P.R., Hutterli, M.A., Stocker, T.F., Ruth, U., Steffensen, J.P., Maggi, V. 2008. Dust-climate couplings over the past 800,000 years from the EPICA Dome C ice core. Nature 452, 616-619. http://doi.org/10.1038/nature06763. 
Lamy, F., Kaiser, J., Ninnemann, U., Hebbeln, D., Arz, H.W., Stoner, J. 2004. Antarctic timing of surface water changes off Chile and Patagonian ice sheet response. Science 304, 1959-1962. https://doi.org/10.1126/science.1097863.

Lumley, S.H., Switsur, R. 1993. Late Quaternary Chronology of the Taitao peninsula, southern Chile. Journal of Quaternary Science 8 (2), 161-165. http://doi.org/10.1002/jqs.3390080208.

Mackintosh, A.N., Barrows, T.T., Colhoun, E.A., Fifield, L.K. 2006. Exposure dating and glacial reconstruction at Mt. Field, Tasmania, Australia, identifies MIS 3 and MIS 2 glacial advances and climatic variability. Journal of Quaternary Science 21,363-376. http://doi.org/10.1002/jqs.989.

Markgraf, V., Whitlock, C., Haberle, S. 2007. Vegetation and fire history during the last 18,000 cal yr B.P. in Southern Patagonia: Mallín Pollux, Coyhaique, Province Aisén (4541'30'S, 7150’30” W, 640 m elevation). Palaeogeography, Palaeoclimatology, Palaeoecology 254 (3-4), 492-507. Doi:http://doi.org/10.1016/j.palaeo.2007.07.008.

Marrero, S.M., Phillips, F.M., Borchers, B., Lifton, N., Aumer, R., Balco, G. 2016a. Cosmogenic nuclide systematics and the CRONUScalc program. Quaternary Geochronology 31, 160 187. http://doi.org/10.1016/j.quageo.2015.09.005.

Marrero, S.M., Phillips, F.M., Caffee, M.W., Gosse, J.C. 2016b. CRONUS-Earth cosmogenic ${ }^{36} \mathrm{Cl}$ calibration. Quaternary Geochronology31,199-219. http://doi.org/10.1016/j.quageo.2015.10.002.

Massaferro, J., Brooks, S.J. 2002. Response of chironomids to late quaternary environmental change in the Taitao Peninsula, Southern Chile. Journal of Quaternary Science 17 (2), 101111. http://dx.doi.org/10.1002/jqs.671.

McCulloch, R., Bentley, M., Tipping, R., Clapperton, C.M. 2005a. Evidence for Late-Glacial Ice Dammed Lakes In The Central Strait Of Magellan And Bahía Inútil, Southernmost South America. Geografiska Annaler, Series A: Physical Geography 87 (2), 335-362. http://doi. org/10.1111/j.0435-3676.2005.00262.x.

McCulloch, R.D., Bentley, M.J., Purves, R.S., Hulton, N.R.J., Sugden, D.E., Clapperton, C.M. 2000. Climatic inferences from glacial and palaeoecological evidence at the last glacial termination, southern South America. Journal of Quaternary Science 15 (4), 409-417. http:// doi.org/10.1002/1099-1417(200005)15:4<409::AID-JQS539>3.0.CO;2-\#.

McCulloch, R.D., Figuerero Torres, M.J., Mengoni Goñalons, G.L., Barclay, R., Mansilla, C. 2016. A Holocene record of environmental change from Rio Zeballos, central Patagonia. The Holocene. https://doi.org/10.1177/0959683616678460.

McCulloch, R.D., Fogwill, C.J., Sugden, D.E., Bentley, M.J., Kubik, P.W. 2005b. Chronology of the Last Glaciation in Central Strait of Magellan and Bahía Inútil, Southernmost South America. Geografiska Annaler, Series A: Physical Geography 87 (2), 289-312. http://doi. org/10.1111/j.0435-3676.2005.00260.x.

Menounos, B., Clague, J.J., Osborn, G., Davis, P.T., Ponce, F., Goehring, B.M., Maurer, M., Rabassa, J.O., Coronato, A., Marr, R. 2013. Latest Pleistocene and Holocene glacier fluctuations in southernmost Tierra del Fuego, Argentina. Quaternary Science Reviews 77, 70-79. http://doi.org/10.1016/j.quascirev.2013.07.008.

Mercer, J.H. 1968. Variations of some Patagonian glaciers since the Late-Glacial. American Journal of Science 266 (2), 91-109. http://dx.doi.org/10.2475/ajs.266.2.91.

Mercer, J.H. 1976. Glacial history of southernmost South America. Quaternary Research 6 (2), 125-166. https://doi.org/10.1016/0033-5894(76)90047-8.

Mercer, J.H. 1982. Holocene glacier variations in southern South America. Striae 18, 35-40.

Mercer, J.H. 1983. Cenozoic glaciation in the Southern Hemisphere. Annual Review Earth Planetary Sciences 11, 99-132. http://doi.org/10.1146/annurev.ea.11.050183.000531.

Montade, V., Combourieu Nebout, N., Kissel, C., Haberle, S.G., Siani, G., Michel, E. 2013. Vegetation and climate changes during the last 22,000yr from a marine core near Taitao Peninsula, southern Chile. Palaeogeography, Palaeoclimatology, Palaeoecology 369, 335 348. http://doi.org/10.1016/j.palaeo.2012.11.001. 
Moreno, P.I., Denton, G.H., Moreno, H., Lowell, T.V., Putnam, A.E., Kaplan, M.R. 2015. Radiocarbon chronology of the last glacial maximum and its termination in northwestern Patagonia. Quaternary Science Reviews 122, 233-249. http://doi.org/10.1016/j. quascirev.2015.05.027.

Moreno, P.I., Kaplan, M.R., François, J.P., Villa-Martínez, R., Moy, C.M., Stern, C.R., Kubik, P.W. 2009. Renewed glacial activity during the Antarctic cold reversal and persistence of cold conditions until $11.5 \mathrm{ka}$ in southwestern Patagonia. Geology 37 (4), 375-378. https:// doi.org/10.1130/G25399A.1.

Pollock, E.W., Bush, A.B.G. 2013. Atmospheric simulations of southern South America's climate since the Last Glacial maximum. Quaternary Science Reviews 71, 219-228. http://doi. org/10.1016/j.quascirev.2012.09.019.

Putnam, A.E., Denton, G.H., Schaefer, J.M., Barrell, D.J.A., Andersen, B.G., Finkel, R.C., Schwartz, R., Doughty, A.M., Kaplan, M.R., Schlüchter, C. 2010. Glacier advance in southern middle-latitudes during the Antarctic Cold Reversal. Nature Geoscience 3, 700704. http://doi.org/10.1038/ngeo962.

Putnam, A.E., Schaefer, J.M., Denton, G.H., Barrell, D.J. a., Birkel, S.D., Andersen, B.G., Kaplan, M.R., Finkel, R.C., Schwartz, R., Doughty, A.M. 2013. The Last Glacial Maximum at $44^{\circ} \mathrm{S}$ documented by a ${ }^{10} \mathrm{Be}$ moraine chronology at Lake Ohau, Southern Alps of New Zealand. Quaternary Science Reviews 62, 114-141. http://doi.org/10.1016/j.quascirev.2012.10.034.

Rabassa, J., Clapperton, C.M. 1990. Quaternary Glaciations of the Southern Andes. Quaternary Science Reviews 9, 153-174. https://doi.org/10.1016/0277-3791(90)90016-4.

Rabassa, J., Coronato,A. 2009. Glaciations in Patagonia and Tierra del Fuego during the Ensenadan Stage/Age (Early Pleistocene-earliest Middle Pleistocene). Quaternary International 210 (12), 18-36. http://doi.org/10.1016/j.quaint.2009.06.019.

Rabassa, J., Coronato, A., Bujalesky, G., Salemme, M., Roig, C., Meglioli, A., Heusser, C., Gordillo, S., Roig, F., Borromei, A., Quattrocchio, M. 2000. Quaternary of Tierra del Fuego, Southernmost South America: an updated review. Quaternary International 68-71, 217-240. http://doi.org/10.1016/S1040-6182(00)00046-X.

Rabassa, J.O.J., Coronato, A., Martínez, O. 2011. Late Cenozoic glaciations in Patagonia and Tierra del Fuego: an updated review. Biological Journal of the Linnean Society 103 (2), 316335. http://doi.org/10.1111/j.1095-8312.2011.01681.x.

Rivera, A., Benham, T., Casassa, G., Bamber, J., Dowdeswell, J.A. 2007. Ice elevation and areal changes of glaciers from the Northern Patagonia Icefield, Chile. Global and Planetary Change 59 (1-4), 126-137. http://doi.org/10.1016/j.gloplacha.2006.11.037.

Rodbell,D.T.,Smith,J.A.,Mark,B.G.2009. Glaciation in the Andes during the Lateglacial and Holocene. Quaternary Science Reviews 28, 2165-2212. http://doi.org/10.1016/j.quascirev.2009.03.012.

Rojas, M., Moreno, P., Kageyama, M., Crucifix, M., Hewitt, C., Abe-Ouchi, A., Ohgaito, R., Brady, E.C., Hope, P. 2009. The Southern Westerlies during the last glacial maximum in PMIP2 simulations. Climate Dynamics 32 (4), 525-548. http://doi.org/10.1007/s00382-008-0421-7.

Rother, H., Shulmeister, J., Fink, D., Alexander, D., Bell, D. 2015. Surface exposure chronology of the Waimakariri glacial sequence in the Southern Alps of New Zealand: Implications for MIS-2 ice extent and LGM glacial mass balance. Earth and Planetary Science Letters 429, 69-81. http://doi.org/10.1016/j.eps1.2015.07.033.

Sagredo, E.A., Lowell, T.V., Kelly, M.A., Rupper, S., Aravena, J.C., Ward, D.J., Malone, A.G. 2016. Equilibrium line altitudes along the Andes during the Last millennium: Paleoclimatic implications. The Holocene. https://doi.org/10.1177/0959683616678458.

Sagredo, E.A., Moreno, P.I., Villa-Martínez, R., Kaplan, M.R., Kubik, P.W., Stern, C.R. 2011. Fluctuations of the Última Esperanza ice lobe $\left(52^{\circ} \mathrm{S}\right)$, Chilean Patagonia, during the last glacial maximum and termination 1. Geomorphology 125 (1), 92-108. http://doi. org/10.1016/j.geomorph.2010.09.007. 
Schaefer, J.M., Denton, G.H., Barrell, D.J.A., Ivy-Ochs, S., Kubik, P.W., Andersen, B.G., Phillips, F.M., Lowell, T. V., Schlüchter, C. 2006. Near-Synchronous Interhemispheric Termination of the Last Glacial Maximum in Mid-Latitudes. Science 312, 1510-1513. https://doi. org/10.1126/science.1122872.

Schaefer, J.M., Putnam, A.E., Denton, G.H., Kaplan, M.R., Birkel, S., Doughty, A.M., Kelley, S., Barrell, D.J.A., Finkel, R.C., Winckler, G., Anderson, R.F., Ninneman, U.S., Barker, S., Schwartz, R., Andersen, B.G., Schluechter, C. 2015. The Southern Glacial Maximum 65,000 years ago and its Unfinished Termination. Quaternary Science Reviews 114, 52-60. http://doi. org/10.1016/j.quascirev.2015.02.009.

Siani, G., Colin, C., Michel, E., Carel, M., Richter, T., Kissel, C., Dewilde, F. 2010. Late Glacial to Holocene terrigenous sediment record in the Northern Patagonian margin: Paleoclimate implications. Palaeogeography, Palaeoclimatology, Palaeoecology 297 (1), 26-36. http:// doi.org/10.1016/j.palaeo.2010.07.011.

Singer, B.S., Ackert, R.P., Guillou, H. 2004. 40Ar/39Ar and K-Ar chronology of Pleistocene glaciations in Patagonia. Geological Society of America Bulletin 116 (3-4), 434-450. http:// doi.org/10.1130/B25177.1.

Smedley, R.K., Glasser, N.F., Duller, G.A.T. 2016. Luminescence dating of glacial advances at Lago Buenos Aires ( $\left.46^{\circ} \mathrm{S}\right)$, Patagonia. Quaternary Science Reviews 134, 59-73. http://doi. org/10.1016/j.quascirev.2015.12.010.

Stern, C.R. 2004. Active Andean volcanism: its geologic and tectonic setting. Revista Geológica de Chile 31 (2), 1-51.

Strelin, J.A., Denton, G.H., Vandergoes, M.J., Ninnemann, U.S., Putnam, A.E. 2011. Radiocarbon chronology of the late-glacial Puerto Bandera moraines, Southern Patagonian Icefield, Argentina. Quaternary Science Reviews 30, 19-20, 2551-2569. http://doi.org/10.1016/j. quascirev.2011.05.004.

Strelin, J.A., Kaplan, M.R., Vandergoes, M.J., Denton, G.H., Schaefer, J.M. 2014. Holocene glacier history of the Lago Argentino basin, Southern Patagonian Icefield. Quaternary Science Reviews 101, 124-145. http://doi.org/10.1016/j.quascirev.2014.06.026.

Sugden, D.E., Bentley, M.J., Fogwill, C.J., Hulton, N.R.J., McCulloch, R.D., Purves, R.S. 2005. Late-Glacial Glacier Events in Southernmost South America: a Blend of 'Northern' and 'Southern' Hemispheric Climatic Signals? Geografiska Annaler, Series A: Physical Geography 87 (2), 273-288. http://doi.org/10.1111/j.0435-3676.2005.00259.x.

Sugden, D.E., McCulloch, R.D., Bory, A.J.-M., Hein, A.S. 2009. Influence of Patagonian glaciers on Antarctic dust deposition during the last glacial period. Nature Geoscience 2 (4), 281-285. http://doi.org/10.1038/ngeo474.

Sylwan, C.A. 1989. Paleomagnetism, paleoclimate, and chronology of Late Cenozoic deposits in southern Argentina. Stockholm University.

Toggweiler, J.R., Russell, J.L., Carson, S.R. 2006. Midlatitude westerlies, atmospheric $\mathrm{CO}_{2}$, and climate change during the ice ages. Paleoceanography 21 (2), 1-15. http://doi. org/10.1029/2005PA001154.

Turner, K.J., Fogwill, C.J., McCulloch, R.D., Sugden, D.E. 2005. Deglaciation of The Eastern Flank Of The North Patagonian Icefield And Associated Continental-Scale Lake Diversions. Geografiska Annaler, Series A: Physical Geography 87 (2), 363-374. http://doi.org/10.1111/ j.0435-3676.2005.00263.x.

Turney, C.S.M., Roberts, R.G., de Jonge, N., Prior, C., Wilmshurst, J.M., McGlone, M.S., Cooper, J. 2007. Redating the advance of the New Zealand Franz Josef Glacier during the Last Termination: evidence for asynchronous climate change. Quaternary Science Reviews 26, 3037-3042. http://doi.org/10.1016/j.quascirev.2007.09.014.

Van Daele, M., Bertrand, S., Meyer, I., Moernaut, J., Vandoorne, W., Siani, G., Tanghe, N., Ghazoui, Z., Pino, M., Urrutia, R., De Batist, M. 2016. Late Quaternary evolution of Lago 
Castor (Chile, $\left.45.6^{\circ} \mathrm{S}\right)$ : Timing of the deglaciation in northern Patagonia and evolution of the southern westerlies during the last 17 kyr. Quaternary Science Reviews 133, 130-146. http:// doi.org/10.1016/j.quascirev.2015.12.021.

Vandekerkhove, E., Bertrand, S., Reid, B., Bartels, A., Charlier, B. 2016. Sources of dissolved silica to the fjords of northern Patagonia $\left(44-48^{\circ} \mathrm{S}\right)$ : The importance of volcanic ash soil distribution and weathering. Earth Surface Processes and Landforms 41 (4), 499-512. http:// doi.org/10.1002/esp.3840.

Vanneste, H., De Vleeschouwer, F., Martínez-Cortizas, A., von Scheffer, C., Piotrowska, N., Coronato, A., Le Roux, G. 2015. Late-glacial elevated dust deposition linked to westerly wind shifts in southern South America. Scientific reports 5, 11670. http://doi.org/10.1038/ srep11670.

Villa-Martínez, R., Moreno, P.I., Valenzuela, M.A. 2012. Deglacial and postglacial vegetation changes on the eastern slopes of the central Patagonian Andes $\left(47^{\circ} \mathrm{S}\right)$. Quaternary Science Reviews 32, 86-99. http://doi.org/10.1016/j.quascirev.2011.11.008.

Völker, D., Geersen, J., Contreras-Reyes, E., Reichert, C. 2013. Sedimentary fill of the Chile Trench $\left(32-46^{\circ} \mathrm{S}\right)$ : volumetric distribution and causal factors. Journal of the Geological Society 170 (5), 723-736. https://doi.org/10.1144/jgs2012-119.

Warren, C.R., Sugden, D.E. 1993. The Patagonian Icefields: A Glaciological Review. Arctic and Alpine Research 25 (4), 316-331. http://doi.org/10.2307/1551915. 